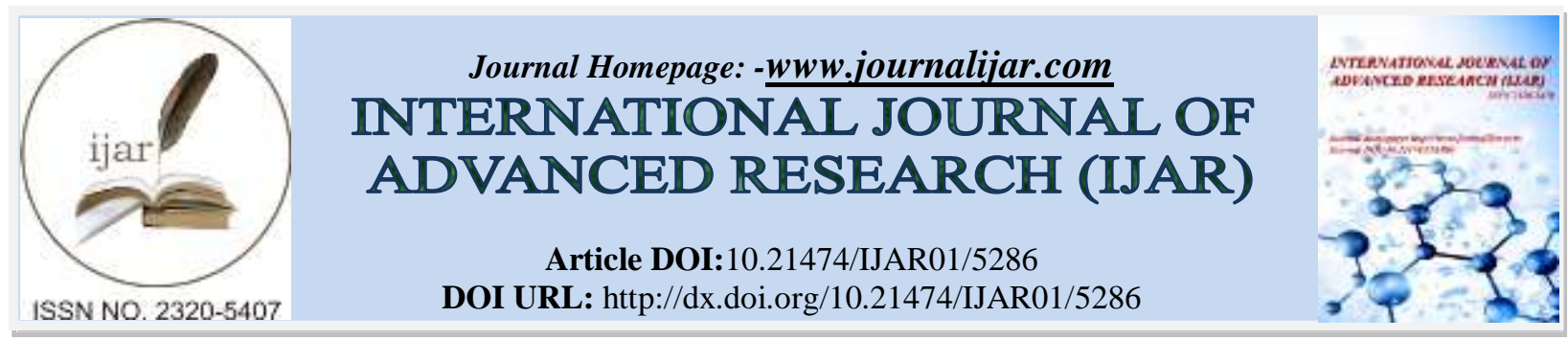

RESEARCH ARTICLE

\title{
SYNTHESIS, CHARACTERIZATION, THERMAL AND ANTIMICROBIAL STUDIES OF SCHIFF BASE M(II) COMPLEXES.
}

Asha M S ${ }^{1}$, Othbert Pinto ${ }^{1}$, Joseph N Sebastian ${ }^{1}$, Sumana Naik ${ }^{1}$ and Shaukath Ara Khanum ${ }^{2}$.

1. Department of Chemistry, St. Philomena's College Bannimantap, Mysuru, Karnataka, India.

2. Department of Chemistry, Yuvaraja's college, Mysuru, Karnataka, India.

\section{Manuscript Info}

Manuscript History

Received: 26 June 2017

Final Accepted: 28 July 2017

Published: August 2017

Keywords:-

Benzophenone; Schiff base; Metal(II)

complexes; Antimicrobial.

\begin{abstract}
The N, O type Schiff base ligand and its five new metal complexes of $\mathrm{Co}(\mathrm{II}), \mathrm{Ni}(\mathrm{II}), \mathrm{Zn}(\mathrm{II}), \mathrm{Cd}(\mathrm{II})$ and $\mathrm{Cu}(\mathrm{II})$ derivatives of 6 -acetyl-7 hydroxy 4,8-dimethyl-2H-chromen-2-one have been synthesized from o-phenylenediamine in alcoholic medium. A series of metal complexes have been characterized quantitatively and qualitatively by using micro elemental analysis, FT-IR, ${ }^{1} \mathrm{H}$ NMR, Mass, UV-Vis, TGA/DTG, ESR, magnetic susceptibility data and molar conductance studies. From the spectral study, all the complexes obtained were octahedral in nature. Complexes exhibited enhanced anti-microbial activity in comparison to their ligand.

Copy Right, IJAR, 2017,. All rights reserved.
\end{abstract}

\section{Introduction:-}

Schiff bases are capable of forming coordinate bonds with many metal ions via azomethine group, and so they have been used for the synthesis of metal complexes due to their easy formation and strong metal binding ability. The Schiff base ligands and their corresponding metal complexes have expanded enormously and include a vast area of organometallic compounds and various aspects of bioinorganic chemistry [1-3] and have continued to play the role of one of the most important stereo chemical models in main group and transition-metal coordination chemistry due to their preparative accessibility, diversity and structural variability $[4,5]$.

Schiff base and its metal complexes attract considerable interest and occupy an important role in the development of chemistry of chelate systems $[6,7]$ due to the fact that especially these with $\mathrm{N}_{2} \mathrm{O}_{2}$ tetradentate ligands, such systems closely resemble metallo-proteins. Some Schiff base complexes are also used as model molecules for biological oxygen carrier systems [8] as well as having applications in analytical fields [9] and have been reported to show a variety of biological actions by virtue of the azomethine linkage, which is responsible for various antibacterial, antifungal, antiviral, anti-inflammatory, antioxidant, anticancer, herbicidal, clinical and analytical activities [10-12]. On the other hand, azo compounds are very important molecules and have attracted much attention in both academic and applied research [13]. Azo compounds and their metal complexes are known to be involved in a number of biological reactions, such as inhibition of DNA, RNA, and protein synthesis, nitrogen fixation, and carcinogenesis $[\mathbf{1 4}, \mathbf{1 5}]$. Also, the azo compounds and their metal-azo complexes are extremely used in dyes and data storage [1618].

As the continuation interest of our study of transition metal complexes, here we present the synthesis and characterization of new complex derivatives of 6-acetyl-7 hydroxy 4,8-dimethyl-2H-chromen-2-one. The antibacterial screening activities of the complexes obtained are carried out and the results are reported herein. 


\section{Experimental section:-}

Materials and Methods:-

All the chemicals used in the preparation of the ligand and its metal complexes were of AR grade. The solvents were distilled before use. For the preparation and analyses, distilled water was used. A Perkin-Elmer CHN analyzer (model 2400) was used for $\mathrm{C}, \mathrm{H}$ and $\mathrm{N}$ analyses. The room temperature molar conductance was determined using a Century digital conductivity meter (model cc 601) with a dip type cell and a smooth platinum electrode. The electronic absorption spectra of the complexes were recorded as dilute solutions on a Shimadzu 160A/240A UVvisible spectrophotometer. The ${ }^{1} \mathrm{H}$ NMR spectra were recorded using Bruker DRX 400 spectrometer at $400 \mathrm{MHz}$ with TMS as the internal standard. Mass spectra were obtained with a VG70-70H spectrophotometer. The infrared spectra of the solid samples were recorded in the range $4000-500 \mathrm{~cm}^{-1}$ on a Perkin-Elmer 597/1650 spectro photometer using $\mathrm{KBr}$ pellets. The magnetic moments were measured out using gouy balance. The TG-DTG experiments were carried out in air using a Shimadzu DT-40 thermal analyzer. The heating rate employed was $10^{\circ} \mathrm{C}$ per minute and platinum cups were used to hold about $5 \mathrm{mg}$ of the samples [19].

Scheme:- Synthesis of Schiff base and its metal complexes.

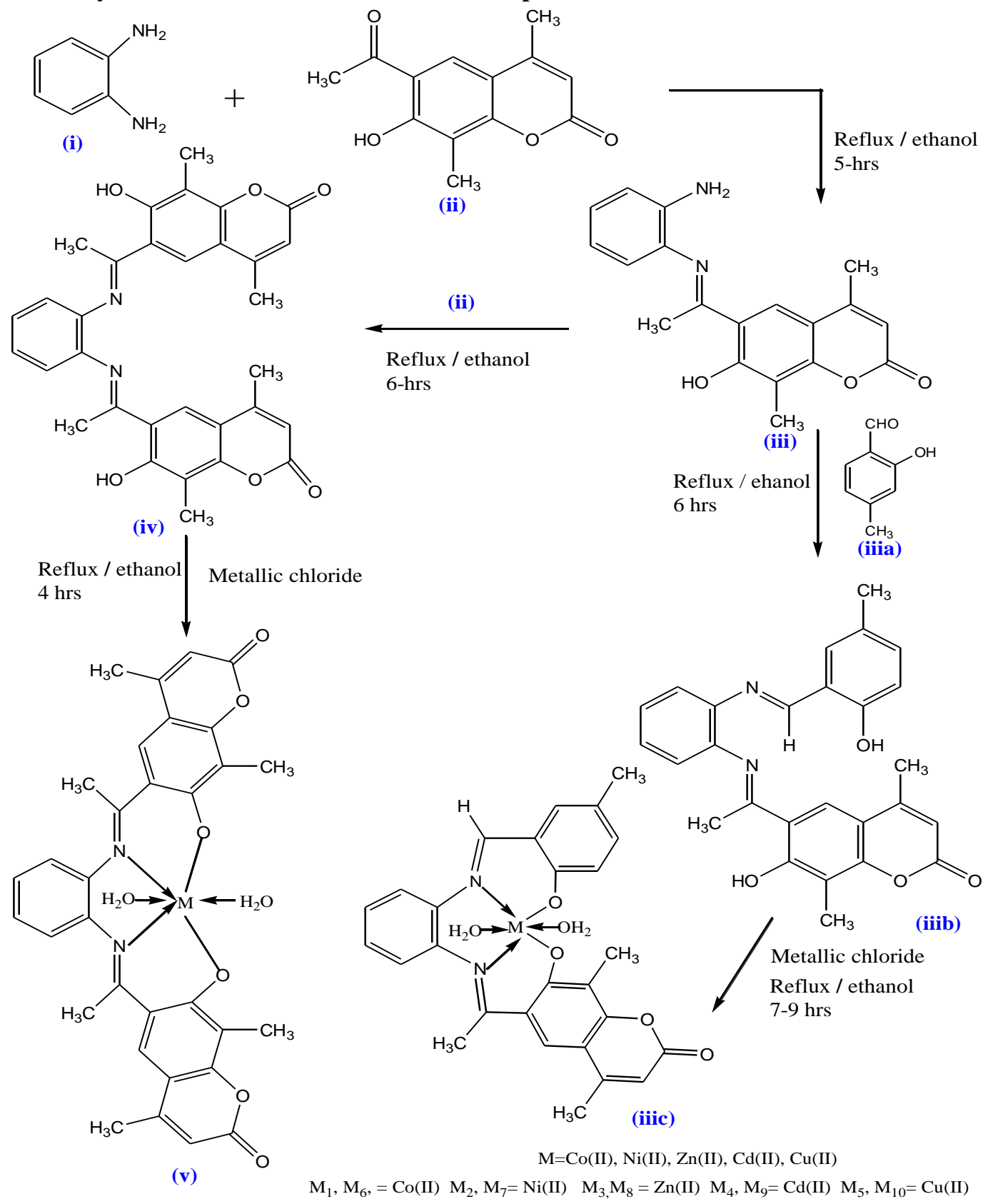


General procedure for the synthesis of 2-methyl-4-\{phenyl-[3-(-1-phenyl-ethyledeneamino)-propylimino]methyl\}-phenol (iii):-

The compound (iii) was prepared by a modification of reported method [20]. A mixture of 6-acetyl-7hydroxy4,8dimethyl-2H-chromen-2-one (ii) and o-phenylene diamine in 1:1 molar ratio was refluxed in dry ethanol for about 3 hours. Then it was cooled to room temperature. On cooling, the white coloured intermediate solid compound, monoSchiff base (iii) was obtained. The solid was washed with distilled water $(3 \times 40 \mathrm{ml})$ and recrystallized from ethanol to achieve pure compound.

Yield 87\%; M.p. $152^{\circ} \mathrm{C}$; IR (Nujol): (C=N) 1662, (O-H) 3510, $\left(-\mathrm{NH}_{2}\right) 3296 \mathrm{~cm}^{-1} .{ }^{1} \mathrm{H}$ NMR (DMSO): $\delta 1.02$ (s, 3H, $\left.\mathrm{N}=\mathrm{C}-\mathrm{CH}_{3}\right), \delta 2.35\left(\mathrm{~s}, 3 \mathrm{H}\right.$, Coumarin $\left.\mathrm{CH}_{3}\right), \delta 2.57\left(\mathrm{~s}, 3 \mathrm{H}, \mathrm{Ar}-\mathrm{CH}_{3}\right), 4.27\left(\mathrm{bs}, 2 \mathrm{H},-\mathrm{NH}_{2}\right), \delta 6.25(\mathrm{~s}, 1 \mathrm{H}$, Coumarin H), $7.93\left(\mathrm{~s}, 1 \mathrm{H}\right.$, Coumarin -H), $\delta$ 6.57-7.01 (m, 4H, Ar-H), 11.63 (bs, 1H, -OH),. MS: m/z $322\left(\mathrm{M}^{+}, 60\right), 232$ (65), relative abundance; $100 \%$. Anal.Calcd. for $\mathrm{C}_{19} \mathrm{H}_{18} \mathrm{~N}_{2} \mathrm{O}_{3}$ (322): C, 70.79; H, 5.63; N, 8.69. Found: C, 70.50; H, 5.55; $\mathrm{N}, 8.60 \%$.

General procedure for the synthesis of ligand 7-hydroxy-6-(1-\{2-[(2-hydroxy-5-methyl-benzylidene)-amino]phenylimino]-ethyl)-4,8-dimethyl-chromen-2-one (iiib):-

Equimolar concentration of 4-methyl-2 hydroxybenzaldehyde (iiia) and intermediate (iii) was refluxed in dry ethanol for 6 hours. The yellow precipitate thus formed (iiib) was filtered, washed with distilled water dried in vaccum over calcium chloride and recrystallized in ethanol.

Yield 89\%; M.p. $167^{\circ} \mathrm{C}$; IR (Nujol): (C-O) 1236, (C-N) 1384, (C=N) 1676, (C=O) 1746, (O-H) $3512 \mathrm{~cm}^{-1} .{ }^{1} \mathrm{H}$ NMR (DMSO): $\delta 1.03\left(\mathrm{~s}, 3 \mathrm{H}, \mathrm{N}=\mathrm{C}-\mathrm{CH}_{3}\right), \delta 2.34\left(\mathrm{~s}, 3 \mathrm{H}\right.$, coumarin $\left.\mathrm{CH}_{3}\right), \delta 2.56\left(\mathrm{~s}, 6 \mathrm{H}, \mathrm{Ar}_{-} \mathrm{CH}_{3}\right), 6.38(\mathrm{~s}, 1 \mathrm{H}$, coumarin $\mathrm{H}), \delta 6.96(\mathrm{~d}, 2 \mathrm{H}, \mathrm{Ar}-\mathrm{H}), \delta 7.07 \quad(\mathrm{~s}, \mathrm{H}, \mathrm{Ar}-\mathrm{H}), \delta$ 7.3-7.4 (m, 4H, Ar-H), $7.95(\mathrm{~s}, \mathrm{H}$, coumarin H), $\delta 8.67(\mathrm{~s}, \mathrm{H}, \mathrm{N}=\mathrm{C}-$ $\mathrm{H}), \delta 11.27(\mathrm{bs}, 2 \mathrm{H},-\mathrm{OH})$. MS: $\mathrm{m} / \mathrm{z} 440\left(\mathrm{M}^{+}, 60\right), 336(10), 216(60), 104$ (70), relative abundance; $92 \%$. Anal.Calcd. for $\mathrm{C}_{27} \mathrm{H}_{24} \mathrm{~N}_{2} \mathrm{O}_{4}$ (440): C, 73.62; H, 5.49; N, 6.36. Found: C, 73.52; H, 5.38; N, 6.25\%.

General procedure for the synthesis of complexes (iiic $\mathbf{M}_{1}-\mathbf{M}_{5}$ ):-

For a solution of ligand (iiib), metal chloride in 1:1 molar ratio in ethanol was added under constant stirring. The pH of the reaction mixture was adjusted to 7-8 by adding $10 \%$ alcoholic ammonia solution and refluxed for about 6-9 hours. The colored precipitate (iiic $\mathbf{M}_{\mathbf{1}}-\mathbf{M}_{\mathbf{5}}$ ) of metal complex was filtered off in hot condition and washed with hot ethanol, and dried over calcium chloride in vacuum desiccators.

Co(II): Yield 75\%; M.p. >250 ${ }^{\circ}$; IR (Nujol): (M-O) 430, (M-N) 510, (C-O) 1263, (C-N) 1392, (C=N) 1665, (C=O) 1766, $\left(\mathrm{H}_{2} \mathrm{O}\right) 3263 \mathrm{~cm}^{-1}$. MS: m/z $534\left(\mathrm{M}^{+}, 80\right), 438$ (60), 215 (10), 103 (55), relative abundance; 83\%. Anal.Calcd. for $\mathrm{C}_{27} \mathrm{H}_{26} \mathrm{~N}_{2} \mathrm{O}_{6} \mathrm{Co}$ (534): C, 60.52; H, 4.32; N, 5.01. Found: C, 60.67; H, 4.86; N, 5.24\%. Molar conductance: 21.0, Magnetic moment: $4.68 \mathrm{~B} \mathrm{M}$.

Ni(II): Yield 72\%; M.p. >250 C; IR (Nujol): (M-O) 440, (M-N) 520, (C-O) 1269, (C-N) 1402, (C=N) 1659, (C=O) 1756, $\left(\mathrm{H}_{2} \mathrm{O}\right) 3280 \mathrm{~cm}^{-1}$. MS: $\mathrm{m} / \mathrm{z} 534\left(\mathrm{M}^{+}, 80\right), 439$ (15), 199 (20), 103 (50), relative abundance; 89\%.Anal.Calcd.for $\mathrm{C}_{27} \mathrm{H}_{26} \mathrm{~N}_{2} \mathrm{O}_{6} \mathrm{Ni}$ (534): C, 60.35; H, 4.54; N, 5.01. Found: C, 60.42; H, 4.45; N, 5.25\%. Molar conductance: 15.5, Magnetic moment: $3.45 \mathrm{~B} \mathrm{M}$.

Zn(II): Yield 78\%; M.p. >250 ${ }^{\circ}$; IR (Nujol): (M-O) 420, (M-N) 527, (C-O) 1272, (C-N) 1412, (C=N) 1657, (C=O) $1764,\left(\mathrm{H}_{2} \mathrm{O}\right) 3320 \mathrm{~cm}^{-1}$. MS: m/z $540\left(\mathrm{M}^{+}, 80\right), 439$ (10), 341 (65), 199 (25), relative abundance; 88\%. Anal.Calcd. for $\mathrm{C}_{27} \mathrm{H}_{26} \mathrm{~N}_{2} \mathrm{O}_{6} \mathrm{Zn}(540)$ : C, 60.02; H, 4.81; N, 5.18. Found: C, 60.15; H, 4.35; N, 5.05\%.Molar conductance: 19.7. Cd(II): Yield 71\%; M.p. >250 ${ }^{\circ} \mathrm{C}$; IR (Nujol): (M-O) 445, (M-N) 530, (C-O) 1275, (C-N) 1410, (C=N) 1663, (C=O) 1762, $\left(\mathrm{H}_{2} \mathrm{O}\right) 3375 \mathrm{~cm}^{-1}$. MS: m/z $588\left(\mathrm{M}^{+}, 100\right), 438$ (05), 389 (25), 199 (10), 103 (30), relative abundance; $67 \%$. Anal.Calcd. for $\mathrm{C}_{27} \mathrm{H}_{26} \mathrm{~N}_{2} \mathrm{O}_{6} \mathrm{Cd}$ (588): C, 55.25; H, 4.12; N, 4.35. Found: C, 55.10; H, 4.42; N, 4.76\%. Molar conductance: 14.2 .

$\mathrm{Cu}$ (II): Yield 75\%; M.p. >250 C; IR (Nujol): (M-O) 425, (M-N) 532, (C-O) 1273, (C-N) 1407, (C=N) 1664, (C=O) 1765, $\left(\mathrm{H}_{2} \mathrm{O}\right) 3403 \mathrm{~cm}^{-1}$. MS: $\mathrm{m} / \mathrm{z}$ 538( $\left.\mathrm{M}^{+}, 45\right), 439(35), 339(65), 103$ (15), relative abundance; 82\%. Anal.Calcd. For $\mathrm{C}_{27} \mathrm{H}_{26} \mathrm{~N}_{2} \mathrm{O}_{6} \mathrm{Cu}(538)$ : C, 60.22; H, 4.83; N, 5.20. Found: C, 60.35; H, 4.53; N, 5.15\%. Molar conductance: 18.8, Magnetic moment: $1.91 \mathrm{~B} \mathrm{M}$. 
General Procedure for the synthesis of ligand di[1,2-7-Hydroxy-6-(1-imino-ethyl)]-4,8-dimethyl-chromen-2one]benzene(iv):-

A mixture of 6-acetyl-7hydroxy4,8-dimethyl-2H-chromen-2-one (ii) and intermediate (iii)in 1:1 molar ratio was refluxed in dry ethanol for about 4 hours. The yellow precipitate thus formed (iv) was filtered, washed with distilled water $(3 \times 30 \mathrm{ml})$ dried in vaccum over Calcium chloride and recrystallized in ethanol.

Yield 85\%; M.p. $152^{\circ} \mathrm{C}$; IR (Nujol): (C-O) 1222, (C-N) 1398, (C=N) 1658, (C=O) 1756, (O-H) $3519 \mathrm{~cm}^{-1} . \mathrm{MS}: \mathrm{m} / \mathrm{z}$ $536\left(\mathrm{M}^{+}, 80\right), 320(60), 216(25), 104$ (100), relative abundance; 88\%. Anal.Calcd.forC ${ }_{32} \mathrm{H}_{28} \mathrm{~N}_{2} \mathrm{O}_{6}$ (536): C, 71.63 ; H, 5.26; N, 5.22. Found: C, 71.33; H, 5.58; N, 5.90\%.

\section{General procedure for the synthesis of complexes $\left(v \mathrm{M}_{6}-\mathrm{M}_{10}\right)$ :-}

For a solution of ligand (iv), metal chloride in 1:1 molar ratioin ethanol was added under constant stirring. The $\mathrm{pH}$ of the reaction mixture was adjusted to 7-8 by adding 10\% alcoholic ammonia solution and refluxed for about 4 hours. The colored precipitate $\left(\mathbf{v ~ M}_{6}-\mathrm{M}_{10}\right)$ of metal complex was filtered off in hot condition and washed with hot ethanol, and dried over calcium chloride in vacuum desiccator.

Co(II): Yield 75\%; M.p. >250 C; IR (Nujol): (M-O) 415, (M-N) 510, (C-O) 1256, (C-N) 1410, (C=N) 1645, (C=O) 1766, $\left(\mathrm{H}_{2} \mathrm{O}\right) 3230 \mathrm{~cm}^{-1}$. MS: $\mathrm{m} / \mathrm{z} 630\left(\mathrm{M}^{+}, 80\right), 534(10), 431$ (25), relative abundance; 86\%. Anal.Calcd. for $\mathrm{C}_{32} \mathrm{H}_{30} \mathrm{~N}_{2} \mathrm{O}_{8} \mathrm{Co}(630)$ : C, 60.95; H, 4.76; N, 4.44. Found: C, 60.58; H, 4.30; N, 4.21\%. Molar conductance: 20.8. Magnetic moment: 4.87 B M.

Ni(II): Yield 72\%; M.p. >250 C; IR (Nujol): (M-O) 424, (M-N) 516, (C-O) 1265, (C-N) 1420, (C=N) 1638, (C=O) 1768, $\left(\mathrm{H}_{2} \mathrm{O}\right) 3300 \mathrm{~cm}^{-1} . \mathrm{MS}: \mathrm{m} / \mathrm{z} 630\left(\mathrm{M}^{+}, 80\right), 534$ (55), 432 (15), 199 (60), 124 (90), relative abundance; 83\%. Anal.Calcd. for $\mathrm{C}_{32} \mathrm{H}_{30} \mathrm{~N}_{2} \mathrm{O}_{8} \mathrm{Ni}(630)$ : C, 61.05; H, 4.82; N, 4.56. Found: C, 61.25; H, 4.62; N, 4.31\%.Molar conductance: 16.7, Magnetic moment: $3.39 \mathrm{~B} \mathrm{M}$.

Zn(II): Yield 78\%; M.p. >250 C; IR (Nujol): (M-O) 425, (M-N) 520, (C-O) 1267, (C-N) 1422, (C=N) 1642, (C=O) 1770, $\left(\mathrm{H}_{2} \mathrm{O}\right) 3310 \mathrm{~cm}^{-1}$. MS: $\mathrm{m} / \mathrm{z}$ 636( $\left.\mathrm{M}^{+}, 95\right), 534(25), 422(15), 104$ (55), relative abundance; 88\%. Anal.Calcd. for $\mathrm{C}_{32} \mathrm{H}_{30} \mathrm{~N}_{2} \mathrm{O}_{8} \mathrm{Zn}(636)$ : C, 60.37; H, 4.71; N, 4.40. Found: C, 60.98; H, 4.90; N, 4.15\%. Molar conductance: 20.2 B M.

Cd(II): Yield 74\%; M.p. >250 C; IR (Nujol): (M-O) 421, (M-N) 515, (C-O) 1260, (C-N) 1415, (C=N) 1647, (C=O) 1775, $\left(\mathrm{H}_{2} \mathrm{O}\right) 3350 \mathrm{~cm}^{-1}$. MS: $\mathrm{m} / \mathrm{z} 682\left(\mathrm{M}^{+}, 90\right), 534(15), 216$ (55), 104 (95), relative abundance; $71 \%$. Anal.Calcd. for $\mathrm{C}_{32} \mathrm{H}_{30} \mathrm{~N}_{2} \mathrm{O}_{8} \mathrm{Cd}(682)$ : C, 56.30; H, 4.39; N, 4.10. Found: C, 56.75; H, 4.50; N, 4.72\%. Molar conductance: 14.8 . $\mathrm{Cu}$ (II): Yield 78\%; M.p. >250 ${ }^{\circ} \mathrm{C}$; IR (Nujol): (M-O) 429, (M-N) 525, (C-O) 1273, (C-N) 1437, (C=N) 1637, (C=O) 1776, $\left(\mathrm{H}_{2} \mathrm{O}\right) 3382 \mathrm{~cm}^{-1}$. MS: $\mathrm{m} / \mathrm{z} 634\left(\mathrm{M}^{+}, 98\right), 534(20), 418$ (35), relative abundance; 81\%. Anal.Calcd. for $\mathrm{C}_{32} \mathrm{H}_{30} \mathrm{~N}_{2} \mathrm{O}_{8} \mathrm{Cu}$ (634): C, 60.56; H, 4.75; N, 4.41. Found: C, 60.15; H, 4.89; N, 4.79\%. Molar conductance: 19.5, Magnetic moment: $1.98 \mathrm{~B}$ M.

\section{Biology:-}

Tested microbes for antimicrobial activity:-

Streptomycin and ciprofloxacin (Sigma) were used as positive controls against bacteria. fluconazole and ketoconazole (Himedia, Mumbai) were used as positive controls against fungi. The following gram positive bacteria were used for the experiments; Micrococcus luteus (MTCC 1538), Staphylococcusaureus (MRSA), Staphylococcusaureus (MTCC 7443), (MTCC 84), Enterobacteraerogenes (MTCC 111). The gram negative bacteria included Salmonella typhimurium (MTCC 2488), Salmonella paratyphi-B (MTCC 733), Proteus vulgaris (MTCC 321) and Klebsiellapneumonia (MTCC 109). In addition, fungi Botyritiscinerea (MTCC 2880), Candidaalbicans (MTCC 227), M. pachydermatisand Candida krusei (MTCC 231) were also used for the experiments.

\section{Preparation of inoculums:-}

Bacterial inoculums were prepared by growing cells in Mueller Hinton Broth (MHA) (Himedia) for $24 \mathrm{~h} \mathrm{at} 37^{\circ} \mathrm{C}$. These cell suspensions were diluted with sterile MHA to provide initial cell counts of about $104 \mathrm{CFU} / \mathrm{ml}$. The filamentous fungi were grown on sabouraud dextrose agar (SDA) slants at $28^{\circ} \mathrm{C}$ for 10 days and the spores were collected using sterile doubled distilled water and homogenized. 


\section{Disc diffusion assay:-}

Antibacterial activity was carried out using a disc diffusion method [21]. Petri plates were prepared with $20 \mathrm{ml}$ of sterile Mueller Hinton Agar (MHA) (Himedia, Mumbai). The test cultures were swabbed on the top of the solidified media and allowed to dry for 10 mins. The tests were conducted at $1000 \mu \mathrm{g} / \mathrm{disc}$. The loaded discs were placed on the surface of the medium and left for $30 \mathrm{~min}$ at room temperature for compound diffusion. Negative control was prepared using respective solvent. Streptomycin $(10 \mu \mathrm{g} / \mathrm{disc})$ was used as positive control. The plates were incubated for $24 \mathrm{~h}$ at $37^{\circ} \mathrm{C}$ for bacteria and $48 \mathrm{~h}$ at $27^{\circ} \mathrm{C}$ for fungi. A zone of inhibition was recorded in millimeters and the experiment was repeated twice.

\section{Minimum inhibitory concentration (MIC):-}

Minimum inhibitory concentration studies of synthesized compounds were performed according to the standard reference method for bacteria [22] and filamentous fungi [23] (CLSI 2008). Required concentrations (1000 $\mu \mathrm{g} / \mathrm{ml}$, $500 \mu \mathrm{g} / \mathrm{ml}, 250 \mu \mathrm{g} / \mathrm{ml}, 125 \mu \mathrm{g} / \mathrm{ml}, 62.5 \mu \mathrm{g} / \mathrm{ml}, 31.25 \mu \mathrm{g} / \mathrm{ml}$ and $15.62 \mu \mathrm{g} / \mathrm{ml}$ ) of the compounds were dissolved in DMSO (2\%), and diluted to give serial two fold dilutions that were added to each medium in 96 well plates. An inoculum of $100 \mathrm{ml}$ from each well was inoculated. The antifungal agent's ketoconazole, fluconazole for fungi and streptomycin, ciprofloxacin for bacteria were included in the assays as positive controls. For fungi, the plates were incubated for $48-72 \mathrm{~h}$ at $28^{\circ} \mathrm{C}$ and for bacteria the plates were incubated for $24 \mathrm{~h}$ at $37^{\circ} \mathrm{C}$. The MIC for fungi was defined as the lowest extract concentration, showing no visible fungal growth after incubation time. $5 \mathrm{ml}$ of tested broth was placed on the sterile MHA plates for bacteria and incubated at respective temperatures. The MIC for bacteria was determined as the lowest concentration of the compound inhibiting the visual growth of the test cultures on the agar plate.

\section{Results and Discussion:- \\ Chemistry:-}

2-methyl-4-\{phenyl-[3-(-1-phenyl-ethyledeneamino)-propylimino]-methyl\}-phenol (iii) was synthesized by the condensation of o-phenylenediamine (i) and 6-Acetyl-7 hydroxy 4, 8-dimethyl-2H-chromen-2-one (ii) (1: 1 molar ratio), dissolved in dry ethanol. The reaction mixture was stirred for 3 hrs. On cooling white coloured intermediate solid compound, mono-Schiff base of 2-methyl-4-\{phenyl-[3-(-1-phenyl-ethyledeneamino)-propylimino]-methyl\}phenol (iii) was obtained. The product is confirmed by NMR and mass spectra.

The product (iii) obtained was treated with an equimolar volume of 4- methyl -2 hydroxybenzaldehyde (iiia) in dry ethanol and stirred for 6 hours with a few drops of glacial acetic acid. The white solid precipitate of Schiff base (iiib) obtained was recrystallized from ethanol. Formation of Schiff base is confirmed by IR, ${ }^{1} \mathrm{H}$ NMR and mass.

Aqueous ethanolic solution of metal chloride of $\mathrm{Co}(\mathrm{II}), \mathrm{Ni}(\mathrm{II}), \mathrm{Zn}(\mathrm{II}), \mathrm{Cd}(\mathrm{II})$ and $\mathrm{Cu}(\mathrm{II})$ were added to the hot ethanolic solution of the ligand (iiib) in 1:1 molar ratio. The $\mathrm{pH}$ of the reaction mixture was adjusted to 7-8 by adding 10\% alcoholic ammonia solution and refluxed for about 7-9 hrs which resulted in the precipitation of metal derivatives in all the cases (iiic $\mathbf{M}_{\mathbf{1}}-\mathbf{M}_{\mathbf{5}}$ ).

The ligand di[1,2-7-Hydroxy-6-(1-imino-ethyl)]-4,8-dimethyl-chromen-2-one]benzene (iv) was synthesized by the condensation of 2-methyl-4-\{phenyl-[3-(-1-phenyl-ethyledeneamino)-propylimino]-methyl\}-phenol (iii) and 6acetyl-7 hydroxy 4,8-dimethyl-2H-chromen-2-one (ii) (1:1 molar ratio), dissolved in dry ethanol. The reaction mixture was stirred for 6 hours with a few drops of glacial acetic acid. The yellow solid precipitate of Schiff base (iiib) obtained was recrystallized from ethanol. Formation of Schiff base is confirmed by IR, ${ }^{1}$ HNMR, and mass.

Aqueous ethanolic solution of metal chloride of $\mathrm{Co}(\mathrm{II}), \mathrm{Ni}(\mathrm{II}), \mathrm{Zn}(\mathrm{II}), \mathrm{Cd}(\mathrm{II})$ and $\mathrm{Cu}(\mathrm{II})$ were added to the hot ethanolic solution of the ligand (iv) in 1:1 molar ratio. The $\mathrm{pH}$ of the reaction mixture was adjusted to 7-8 by adding $10 \%$ alcoholic ammonia solution and refluxed for about 7-9 hrs which resulted in the precipitation of metal derivatives in all the cases $\left(\mathbf{v} \mathbf{M}_{\mathbf{6}}-\mathbf{M}_{\mathbf{1 0}}\right)$.

The yield, elemental analysis and molar conductance data of metal complexes are presented in Table 1 and 2. 
Table 1:-Elemental and molar conductance data.

\begin{tabular}{|c|c|c|c|c|c|c|}
\hline \multirow[t]{2}{*}{ Compound (Colour) } & \multirow{2}{*}{$\begin{array}{l}\text { M.p. } \\
\left({ }^{\circ} \mathbf{C}\right)\end{array}$} & \multirow{2}{*}{$\begin{array}{c}\text { Yield } \\
(\%)\end{array}$} & \multicolumn{3}{|c|}{ Found (Calc.) \% } & \multirow{2}{*}{$\begin{array}{c}\Delta \mathrm{m}_{2} \\
\left(\mathrm{ohm}^{-1} \mathrm{~cm}^{2} \mathrm{~mol}^{-1}\right)\end{array}$} \\
\hline & & & $\mathbf{C}$ & H & $\mathbf{N}$ & \\
\hline $\begin{array}{l}\mathrm{C}_{27} \mathrm{H}_{24} \mathrm{~N}_{2} \mathrm{O}_{4} \\
\text { (iiib) White }\end{array}$ & 167 & 89 & $\begin{array}{c}73.62 \\
(73.52)\end{array}$ & $\begin{array}{c}5.49 \\
(5.38)\end{array}$ & $6.36(6.25)$ & - \\
\hline $\begin{array}{l}\mathrm{C}_{27} \mathrm{H}_{22} \mathrm{~N}_{2} \mathrm{O}_{4} \mathrm{Co}\left(\mathrm{H}_{2} \mathrm{O}\right)_{2} \\
\left(\text { iiic } \mathrm{M}_{1}\right) \text { Light brown }\end{array}$ & $>250$ & 75 & $\begin{array}{r}60.52 \\
(60.67) \\
\end{array}$ & $\begin{array}{c}4.32 \\
(4.86) \\
\end{array}$ & $\begin{array}{c}5.01 \\
(5.24) \\
\end{array}$ & 21.0 \\
\hline $\begin{array}{l}\mathrm{C}_{27} \mathrm{H}_{22} \mathrm{~N}_{2} \mathrm{O}_{4} \mathrm{Ni}\left(\mathrm{H}_{2} \mathrm{O}\right)_{2} \\
\left(\text { iiic } \mathrm{M}_{2}\right) \text { Light Yellow }\end{array}$ & $>250$ & 72 & $\begin{array}{c}60.42 \\
(60.35)\end{array}$ & $\begin{array}{c}4.45 \\
(4.54)\end{array}$ & $\begin{array}{c}5.25 \\
(5.01)\end{array}$ & 15.5 \\
\hline $\begin{array}{c}\mathrm{C}_{27} \mathrm{H}_{22} \mathrm{~N}_{2} \mathrm{O}_{4} \mathrm{Zn}\left(\mathrm{H}_{2} \mathrm{O}\right)_{2} \\
\left.\text { (iiic } \mathrm{M}_{3}\right) \text { White }\end{array}$ & $>250$ & 78 & $\begin{array}{c}60.02 \\
(60.15)\end{array}$ & $\begin{array}{c}4.81 \\
(4.35)\end{array}$ & $\begin{array}{c}5.18 \\
(5.05)\end{array}$ & 19.7 \\
\hline $\begin{array}{c}\mathrm{C}_{27} \mathrm{H}_{22} \mathrm{~N}_{2} \mathrm{O}_{4} \mathrm{Cd}\left(\mathrm{H}_{2} \mathrm{O}\right)_{2} \\
\left(\text { iiic } \mathrm{M}_{4}\right) \text { White } \\
\end{array}$ & $>250$ & 71 & $\begin{array}{c}55.10 \\
(55.25) \\
\end{array}$ & $\begin{array}{c}4.42 \\
(4.12) \\
\end{array}$ & $\begin{array}{c}4.76 \\
(4.35) \\
\end{array}$ & 14.2 \\
\hline $\begin{array}{l}\mathrm{C}_{27} \mathrm{H}_{22} \mathrm{~N}_{2} \mathrm{O}_{4} \mathrm{Cu}\left(\mathrm{H}_{2} \mathrm{O}\right)_{2} \\
\left(\text { iiic } \mathrm{M}_{5}\right) \text { Dark green }\end{array}$ & $>250$ & 75 & $\begin{array}{c}60.22 \\
(60.35) \\
\end{array}$ & $\begin{array}{c}4.83 \\
(4.53)\end{array}$ & $\begin{array}{c}5.20 \\
(5.15)\end{array}$ & 18.8 \\
\hline
\end{tabular}

Table 2:-Elemental and molar conductance data.

\begin{tabular}{|c|c|c|c|c|c|c|}
\hline \multirow{2}{*}{$\begin{array}{l}\text { Compound } \\
\text { (Colour) }\end{array}$} & \multirow{2}{*}{$\begin{array}{l}\text { M.p. } \\
\left({ }^{\circ} \mathbf{C}\right)\end{array}$} & \multirow{2}{*}{$\begin{array}{c}\text { Yield } \\
(\%)\end{array}$} & \multicolumn{3}{|c|}{ Found (Calc.) \% } & \multirow{2}{*}{$\begin{array}{c}\Delta \mathrm{m}_{2} \\
\left(\mathrm{ohm}^{-1} \mathrm{~cm}^{2} \mathrm{~mol}^{-1}\right)\end{array}$} \\
\hline & & & $\mathbf{C}$ & $\mathbf{H}$ & $\mathbf{N}$ & \\
\hline $\begin{array}{c}\mathrm{C}_{32} \mathrm{H}_{28} \mathrm{~N}_{2} \mathrm{O}_{6} \\
\text { (iv) Yellow }\end{array}$ & 152 & 85 & $\begin{array}{c}71.63 \\
(71.33)\end{array}$ & $\begin{array}{c}5.26 \\
(5.58)\end{array}$ & $5.22(5.90)$ & - \\
\hline $\begin{array}{c}\mathrm{C}_{32} \mathrm{H}_{30} \mathrm{~N}_{2} \mathrm{O}_{8} \mathrm{Co}\left(\mathrm{H}_{2} \mathrm{O}\right)_{2} \\
\left(\mathrm{v} \mathrm{M}_{6}\right) \text { Dark brown } \\
\end{array}$ & $>250$ & 75 & $\begin{array}{c}60.95 \\
(60.58) \\
\end{array}$ & $\begin{array}{c}4.76 \\
(4.30) \\
\end{array}$ & $\begin{array}{c}4.44 \\
(4.21) \\
\end{array}$ & 20.8 \\
\hline $\begin{array}{l}\mathrm{C}_{32} \mathrm{H}_{30} \mathrm{~N}_{2} \mathrm{O}_{8} \mathrm{Ni}\left(\mathrm{H}_{2} \mathrm{O}\right)_{2} \\
\left(\mathrm{v} \mathrm{M}_{7}\right) \text { Light brown }\end{array}$ & $>250$ & 72 & $\begin{array}{c}61.05 \\
(61.25)\end{array}$ & $\begin{array}{c}4.85 \\
(4.62) \\
\end{array}$ & $\begin{array}{c}4.56 \\
(4.31) \\
\end{array}$ & 16.7 \\
\hline $\begin{array}{c}\mathrm{C}_{32} \mathrm{H}_{30} \mathrm{~N}_{2} \mathrm{O}_{8} \mathrm{Zn}\left(\mathrm{H}_{2} \mathrm{O}\right)_{2} \\
\left(\mathrm{v} \mathbf{M}_{8}\right) \text { White }\end{array}$ & $>250$ & 78 & $\begin{array}{c}60.37 \\
(60.98)\end{array}$ & $\begin{array}{c}4.71 \\
(4.90)\end{array}$ & $4.40(4.15)$ & 20.2 \\
\hline $\begin{array}{c}\mathrm{C}_{32} \mathrm{H}_{30} \mathrm{~N}_{2} \mathrm{O}_{8} \mathrm{Cd}\left(\mathrm{H}_{2} \mathrm{O}\right)_{2} \\
\left(\mathrm{v} \mathrm{M} \mathbf{M}_{9}\right) \text { White }\end{array}$ & $>250$ & 74 & $\begin{array}{c}56.30 \\
(56.75) \\
\end{array}$ & $\begin{array}{c}4.39 \\
(4.50) \\
\end{array}$ & $\begin{array}{c}4.10 \\
(4.72) \\
\end{array}$ & 14.8 \\
\hline $\begin{array}{c}\mathrm{C}_{32} \mathrm{H}_{30} \mathrm{~N}_{2} \mathrm{O}_{8} \mathrm{Cu}\left(\mathrm{H}_{2} \mathrm{O}\right)_{2} \\
\left(\mathrm{v} \mathrm{M}_{10}\right) \text { Dark brown }\end{array}$ & $>250$ & 78 & $\begin{array}{c}60.56 \\
(60.15) \\
\end{array}$ & $\begin{array}{c}4.75 \\
(4.89) \\
\end{array}$ & $\begin{array}{c}4.41 \\
(4.79) \\
\end{array}$ & 19.5 \\
\hline
\end{tabular}

\section{IR Spectra:-}

The IR spectra of the complexes were compared with those of the free ligands in order to determine the coordination sites that may be involved in chelation. There were some guide peaks in the spectra of the ligands, which were helpful in achieving this goal. The IR spectral bands of metal(II) complexes are listed in Table 3.

Table 3:-The important diagnostic IR absorption bands $\left(\right.$ in $\left.\mathrm{cm}^{-1}\right)$ of ligands and their complexes:

\begin{tabular}{|c|c|c|c|c|c|c|c|c|}
\hline Compound & $v\left(\mathbf{H}_{2} \mathbf{O}\right)$ & $v(\mathbf{O}-\mathrm{H})$ & $\begin{array}{c}v \\
(C=0)\end{array}$ & $\begin{array}{c}v \\
(\mathbf{C}=\mathbf{N})\end{array}$ & $\begin{array}{c}v \\
(\mathbf{C}-\mathbf{N})\end{array}$ & $\begin{array}{c}v \\
(\mathrm{C}-\mathrm{O})\end{array}$ & $\begin{array}{c}\mathbf{v} \\
(\mathbf{M}-\mathbf{N})\end{array}$ & $\begin{array}{c}v \\
(\mathbf{M}-\mathbf{O})\end{array}$ \\
\hline $\begin{array}{l}\mathrm{C}_{27} \mathrm{H}_{24} \mathrm{~N}_{2} \mathrm{O}_{4} \\
\text { (iiib) }\end{array}$ & - & 3512 & 1746 & 1676 & 1384 & 1236 & --- & --- \\
\hline $\begin{array}{c}\mathrm{C}_{27} \mathrm{H}_{22} \mathrm{~N}_{2} \mathrm{O}_{4} \mathrm{Co}\left(\mathrm{H}_{2} \mathrm{O}\right)_{2} \\
\text { (iiic } \mathrm{M}_{1} \text { ) }\end{array}$ & 3493 & - & 1766 & 1665 & 1392 & 1263 & 515 & 460 \\
\hline $\begin{array}{c}\mathrm{C}_{27} \mathrm{H}_{22} \mathrm{~N}_{2} \mathrm{O}_{4} \mathrm{Ni}\left(\mathrm{H}_{2} \mathrm{O}\right)_{2} \\
\text { (iiic } \mathrm{M}_{2} \text { ) }\end{array}$ & 3503 & - & 1756 & 1659 & 1402 & 1269 & 595 & 498 \\
\hline $\begin{array}{c}\mathrm{C}_{27} \mathrm{H}_{22} \mathrm{~N}_{2} \mathrm{O}_{4} \mathrm{Zn}\left(\mathrm{H}_{2} \mathrm{O}\right)_{2} \\
\text { (iiic } \mathrm{M}_{3} \text { ) }\end{array}$ & 3498 & - & 1764 & 1657 & 1412 & 1272 & 575 & 505 \\
\hline $\begin{array}{c}\mathrm{C}_{27} \mathrm{H}_{22} \mathrm{~N}_{2} \mathrm{O}_{4} \mathrm{Cd}\left(\mathrm{H}_{2} \mathrm{O}\right)_{2} \\
\text { (iiic } \mathrm{M}_{4} \text { ) }\end{array}$ & 3490 & - & 1762 & 1663 & 1410 & 1275 & 592 & 480 \\
\hline $\begin{array}{c}\mathrm{C}_{27} \mathrm{H}_{22} \mathrm{~N}_{2} \mathrm{O}_{4} \mathrm{Cu}\left(\mathrm{H}_{2} \mathrm{O}\right)_{2} \\
\text { (iiic } \mathrm{M}_{5} \text { ) }\end{array}$ & 3497 & - & 1765 & 1664 & 1407 & 1273 & 525 & 458 \\
\hline $\begin{array}{c}\mathrm{C}_{32} \mathrm{H}_{28} \mathrm{~N}_{2} \mathrm{O}_{6} \\
\text { (iv) }\end{array}$ & - & 3519 & 1756 & 1658 & 1398 & 1222 & --- & $\cdots$ \\
\hline $\mathrm{C}_{32} \mathrm{H}_{30} \mathrm{~N}_{2} \mathrm{O}_{8} \mathrm{Co}\left(\mathrm{H}_{2} \mathrm{O}\right)_{2}$ & 3496 & - & 1766 & 1645 & 1410 & 1256 & 512 & 458 \\
\hline
\end{tabular}




\begin{tabular}{|c|c|c|c|c|c|c|c|c|}
\hline$\left(\mathrm{v} \mathrm{M}_{6}\right)$ & & & & & & & & \\
\hline $\begin{array}{c}\mathrm{C}_{32} \mathrm{H}_{30} \mathrm{~N}_{2} \mathrm{O}_{8} \mathrm{Ni}\left(\mathrm{H}_{2} \mathrm{O}\right)_{2} \\
(\mathrm{v} \mathrm{M})\end{array}$ & $\mathbf{3 4 5 0}$ & - & $\mathbf{1 7 6 8}$ & $\mathbf{1 6 3 8}$ & $\mathbf{1 4 2 0}$ & $\mathbf{1 2 6 5}$ & $\mathbf{5 5 0}$ & $\mathbf{4 6 2}$ \\
\hline $\begin{array}{c}\mathrm{C}_{32} \mathrm{H}_{30} \mathrm{~N}_{2} \mathrm{O}_{8} \mathrm{Zn}\left(\mathrm{H}_{2} \mathrm{O}\right)_{2} \\
\left.(\mathrm{v} \mathrm{M})_{8}\right)\end{array}$ & $\mathbf{3 4 6 0}$ & - & $\mathbf{1 7 7 0}$ & $\mathbf{1 6 4 2}$ & $\mathbf{1 4 2 2}$ & $\mathbf{1 2 6 7}$ & $\mathbf{5 7 5}$ & $\mathbf{4 8 4}$ \\
\hline $\begin{array}{c}\mathrm{C}_{32} \mathrm{H}_{30} \mathrm{~N}_{2} \mathrm{O}_{8} \mathrm{Cd}\left(\mathrm{H}_{2} \mathrm{O}\right)_{2} \\
(\mathrm{v} \mathrm{M})\end{array}$ & $\mathbf{3 4 8 0}$ & - & 1775 & 1647 & $\mathbf{1 4 1 5}$ & $\mathbf{1 2 6 0}$ & $\mathbf{5 7 5}$ & $\mathbf{4 9 6}$ \\
\hline $\begin{array}{c}\mathrm{C}_{32} \mathrm{H}_{30} \mathrm{~N}_{2} \mathrm{O}_{8} \mathrm{Cu}\left(\mathrm{H}_{2} \mathrm{O}\right)_{2} \\
\left(\mathrm{v} \mathrm{M} \mathrm{M}_{10}\right)\end{array}$ & $\mathbf{3 4 5 0}$ & - & $\mathbf{1 7 7 6}$ & $\mathbf{1 6 3 7}$ & $\mathbf{1 4 3 7}$ & $\mathbf{1 2 7 3}$ & $\mathbf{6 3 2}$ & $\mathbf{5 0 5}$ \\
\hline
\end{tabular}

In the IR spectrum of o-phenylenediamine, a pair of bands corresponding to $v\left(\mathrm{NH}_{2}\right)$ was present at 3210 and 3270 $\mathrm{cm}^{-1}$ but was absent in the IR spectra of all the complexes [24]. A single broad medium band at 3157 and $3134 \mathrm{~cm}^{-1}$ was observed in the spectra of ligand iiib and iv respectively, which may be assigned to intramolecularhydrogen bonded $v(\mathrm{OH})$. The absence of $(\mathrm{O}-\mathrm{H})$ stretching and $\mathrm{v}(\mathrm{O}-\mathrm{H})$ vibration in the spectra of the complexes indicated deprotonation of the $-\mathrm{OH}$ groups $[\mathbf{2 5}, \mathbf{2 6}]$.

The phenolic $\mathrm{v}(\mathrm{O}-\mathrm{H})$ band is shifted from 3512 (iiib) and 3519 (iv) to $1263-1275$ (iiic $\mathbf{M}_{\mathbf{1}}-\mathbf{M}_{\mathbf{5}}$ ) and 1256-1273 $\mathrm{cm}^{-1}$ $\left(\mathbf{v} \mathbf{M}_{\mathbf{6}}-\mathbf{M}_{10}\right)$ as a consequence of the delocalization of double bond in chelate rings that has increased the bond order of the phenolic C-O. The phenolic oxygen, after the loss of $\mathrm{O}-\mathrm{H}$ proton gets coordinated to the metal. This is supported by a shift in the stretching frequency of $\mathrm{v}(\mathrm{C}-\mathrm{O})$ to the lower wave numberof its position in the free ligand [27]. A strong peak at 1746 and $1756 \mathrm{~cm}^{-1}$ in the IR spectrum of Schiff base iiib and iv respectively was assigned to the $v(>\mathrm{C}=\mathrm{O})$ stretching moiety. This band was shifted to a higher frequency by $\sim 10-20 \mathrm{~cm}^{-1}$ in the IR spectrum of metal complexes at 1756-1766 (iiic, $\left.\mathbf{M}_{\mathbf{1}}-\mathbf{M}_{\mathbf{5}}\right)$ and $1766-1776 \mathrm{~cm}^{-1}\left(\mathbf{v}, \mathbf{M}_{\mathbf{6}}-\mathbf{M}_{10}\right)$ as compared to the corresponding ligands $[\mathbf{2 8}, \mathbf{2 9}, \mathbf{3 0}]$. The strong band observed in the region 1676 and $1658 \mathrm{~cm}^{-1}$ in the ligands iiib and iv assigned to $\mathrm{C}=\mathrm{N}$ stretching. The complexes show a strong band at $1657-1665 \mathrm{~cm}^{-1}$ (iiic, $\left.\mathbf{M}_{\mathbf{1}}-\mathbf{M}_{5}\right)$ and $1637-1647 \mathrm{~cm}^{-1}\left(\mathbf{v}, \mathbf{M}_{\mathbf{6}^{-}}\right.$ $\mathbf{M}_{10}$ ) band at region, representing the $\mathrm{C}=\mathrm{N}$ stretching moiety. This band is shifted to a lower frequency by $\sim 11-21$ $\mathrm{cm}^{-1}$, as compared to the corresponding ligands indicating that the azomethine nitrogen of the $\mathrm{C}=\mathrm{N}$ group has participated in the coordination [31]. This can be ascribed to the withdrawn of electron density from the nitrogen atom owing to coordination. The bands present at $1384,1398 \mathrm{~cm}^{-1}$ and $1392-1412$ and $1410-1437 \mathrm{~cm}^{-1}$ were assigned to $v(\mathrm{C}-\mathrm{N})$ vibrations. The IR spectra showed bands in the region 510-532 and 510-525 $\mathrm{cm}^{-1}$ corresponding to $v(\mathrm{M}-\mathrm{N})$ vibrations in all the complexes [32]. The presence of this band supports the fact concerning the coordination of the azomethine nitrogen with the metal [33]. The bands present at $420-445$ and $415-429 \mathrm{~cm}^{-1}$ in all complexes were due to $v(\mathrm{M}-\mathrm{O})$ [34]. The IR spectra showed a strong band in 3450-3503 $\mathrm{cm}^{-1}$ region (iiic $\mathbf{M}_{\mathbf{1}}-\mathbf{M}_{\mathbf{5}}$ and $\mathbf{v}, \mathbf{M}_{\mathbf{6}}-\mathbf{M}_{10}$ ) suggesting the presence of coordinated water.

\section{Magnetic susceptibility, electronic and ESR spectral studies:-}

The electronic absorption spectra of the Schiff base ligand and its $\mathrm{Co}(\mathrm{II}), \mathrm{Ni}(\mathrm{II}), \mathrm{Zn}(\mathrm{II}), \mathrm{Cd}(\mathrm{II})$ and $\mathrm{Cu}(\mathrm{II})$ complexes were recorded in DMF solution in the range of 200 to $800 \mathrm{~nm}$ regions and data are presented in Table 4.

The electronic transitions due to the organic ligand in the metal complexes, showed the absorption bands of the $\pi \rightarrow \pi^{*}$ and $\mathrm{n} \rightarrow \pi^{*}$ transitions results from the $\mathrm{C}=\mathrm{N}$ and $\mathrm{O}-\mathrm{H}$ groups and appeared at $273-295 \mathrm{~nm}$ and $360-389 \mathrm{~nm}$ regions, respectively. These values are lower than the corresponding absorption bands for the ligand, which were observed at 390- $394 \mathrm{~nm}$, respectively. This may be due to the coordination of the nitrogen and oxygen atoms of the ligand to the metal ions.

The magnetic moment of the complexes were measured at room temperature. The electronic spectra of the Schiff base ligands and their $\mathrm{Co}(\mathrm{II}), \mathrm{Ni}(\mathrm{II}), \mathrm{Zn}(\mathrm{II}) \mathrm{Co}(\mathrm{II})$ and $\mathrm{Cu}(\mathrm{II})$, complexes have been measured in DMF solution between $200-800 \mathrm{~nm}$ at room temperature. The electronic absorption spectra are often very helpful for structural investigation. The electronic spectral measurements were used for assigning the geometry of metal ions in the complexes based on the positions and number of $\mathrm{d}-\mathrm{d}$ transition peaks. Magnetic properties arise from the spin and orbital angular momentum of the electrons contained in a compound.

The magnetic moment of the complexes were measured at room temperature. The magnetic moment of the cobalt (II) lay in the range 4.68 and $4.87 \mathrm{~B} \mathrm{M}$ (iiic $\mathbf{M}_{\mathbf{1}}$ and $\mathbf{v} \mathbf{M}_{\mathbf{6}}$ ) which corresponds to 3 unpaired electrons. The solution spectra of the cobalt (II) complexes exhibited absorption in the region 290, 350, 440 (iiic $\mathbf{M}_{1}$ ) and 280, 360, $450 \mathrm{~nm}$ 
$\left(\mathbf{v} \mathbf{M}_{\mathbf{6}}\right)$. The spectra resemble that reported for octahedral complex [35]. Thus the various bands can be assigned to:

${ }^{4} \mathrm{~T}_{1} \mathrm{~g} \rightarrow{ }^{4} \mathrm{~T}_{2} \mathrm{~g},{ }^{4} \mathrm{~T}_{1} \mathrm{~g} \rightarrow{ }^{4} \mathrm{~A}_{2} \mathrm{~g},{ }^{4} \mathrm{~T}_{1} \mathrm{~g} \rightarrow{ }^{4} \mathrm{~T}_{1} \mathrm{~g}$.

The magnetic moment of the nickel (II) lay in the range 3.45 and $3.39 \mathrm{BM}$ (iiic $\mathbf{M}_{\mathbf{1}}$ and $\mathbf{v} \mathbf{M}_{\mathbf{6}}$ ) which corresponds to 2 unpaired electrons. The solution spectra of the nickel (II) complexes exhibited absorption in the region 370, 390, 470, 440 (iiic $\mathbf{M}_{1}$ ) and 360, 380, 460, $480 \mathrm{~nm}\left(\mathbf{v ~ M}_{\mathbf{6}}\right.$ ). The spectra resemble that reported for octahedral complex. Thus the various bands can be assigned to: ${ }^{4} \mathrm{~T}_{1} \mathrm{~g} \rightarrow{ }^{4} \mathrm{~T}_{2} \mathrm{~g},{ }^{4} \mathrm{~T}_{1} \mathrm{~g} \rightarrow{ }^{4} \mathrm{~A}_{2} \mathrm{~g},{ }^{4} \mathrm{~T}_{1} \mathrm{~g} \rightarrow{ }^{4} \mathrm{~T}_{1} \mathrm{~g}$ and $\mathrm{L} \rightarrow \mathrm{M}$ charge transfer respectively.

The electronic spectrum of the copper(II) complex shows broad band absorption in the region $675 \mathrm{~nm}, 647 \mathrm{~nm}$ and $515 \mathrm{~nm}$ (iiic $\left.\mathbf{M}_{5}\right), 678 \mathrm{~nm}, 642 \mathrm{~nm}$ and $519 \mathrm{~nm}\left(\mathbf{v ~ M}_{10}\right)$, which may be assign to ${ }^{2} \mathrm{~B}_{1 \mathrm{~g}} \rightarrow{ }^{2} \mathrm{~A}_{1 \mathrm{~g}},\left(\mathrm{dx}^{2}-\mathrm{y}^{2} \rightarrow \mathrm{dz}^{2}\right)\left(v_{1}\right)$, ${ }^{2} \mathrm{~B}_{1 \mathrm{~g}} \rightarrow{ }^{2} \mathrm{~B}_{2 \mathrm{~g}},\left(\mathrm{dx} \mathrm{x}^{2}-\mathrm{y}^{2} \rightarrow \mathrm{dzy}\right)\left(\mathrm{v}_{2}\right)$, and ${ }^{2} \mathrm{~B}_{1 \mathrm{~g}} \rightarrow{ }^{2} \mathrm{E}_{\mathrm{g}},\left(\mathrm{dx}^{2}-\mathrm{y}^{2} \rightarrow \mathrm{dzy}\right.$, dyz) $\left(v_{3}\right)$ transition and it is in conformity with octahedral geometry [36]. The broadness of the band which are similar in energy give rise to only one broad absorption band, and the broadness of the band is due to dynamic Jahn-Teller distortion. These data suggest that the $\mathrm{Cu}$ (II) complex have distorted octahedral geometry [37].

An indication of the most probable geometric configuration of the synthesized metal complexes is their magnetic moment values. So, it has been further confirmed by the magnetic moment measurements, room temperature values lie at 1.91(iiic $\left.\mathbf{M}_{5}\right)$ and $1.98 \mathrm{~B} \mathrm{M}\left(\mathbf{v ~}_{\mathbf{6}}\right)$ corresponding to the presence of one unpaired electron and it supports a distorted octahedral geometry [38, 39].

The ESR spectrum of $\mathrm{Cu}(\mathrm{II})$ complex has been recorded on X-band at frequency $9.1 \mathrm{GHz}$ at low temperature. The spectrum of $\mathrm{Cu}(\mathrm{II})$ (viiM $\mathbf{g}_{\mathbf{9}}$ and vii $_{\mathbf{1 0}}$ ) complex is characteristic of axial symmetry with $\mathrm{g}_{\|}, \mathrm{g}_{\perp}$, and $\Delta \mathrm{g}$ values of 2.40, 2.07, (viiM) and 2.48, $2.07\left(\right.$ viiM $\left._{\mathbf{1 0}}\right) 0.37\left(\mathbf{v i i M}_{\mathbf{9}}\right)$ and $0.39\left(\mathbf{v i i M}_{\mathbf{1 0}}\right)$. Anisotropy of the g-tensor is due to the Jahn-Teller effect, which reduces the symmetry from octahedral to distorted octahedral. The fact that $\mathrm{g}_{\|}>$ $\mathrm{g}_{\perp}>2.0023\left(\mathrm{~g}_{\mathrm{e}}\right)$ and $\mathrm{G}=5.06,>4$ indicates octahedral geometry of the $\mathrm{Cu}(\mathrm{II})$ ion of $\mathrm{d}_{\mathrm{x}-\mathrm{y}}{ }^{2}$ ground state with negligible exchange interaction in the complex [39].

Table 4:-Magnetic susceptibility and electronic spectral data:

\begin{tabular}{|c|c|c|c|c|}
\hline \multirow{2}{*}{$\begin{array}{l}\text { Ligand/ } \\
\text { complexes }\end{array}$} & \multicolumn{3}{|c|}{$\begin{array}{l}\text { Electronic absorption bands and their assignments } \\
\qquad(\mathrm{nm})\end{array}$} & \multirow{2}{*}{ 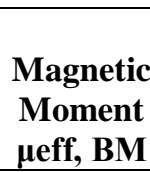 } \\
\hline & $\pi \rightarrow \pi^{*}$ & $\mathrm{n} \rightarrow \pi^{*}$ & $\mathrm{~d} \rightarrow \mathrm{d}$ transition & \\
\hline $\begin{array}{c}\mathrm{C}_{27} \mathrm{H}_{24} \mathrm{~N}_{2} \mathrm{O}_{4} \\
\text { (iiib) }\end{array}$ & 292 & 390 & ---- & --- \\
\hline $\begin{array}{l}\mathrm{C}_{27} \mathrm{H}_{22} \mathrm{~N}_{2} \mathrm{O}_{4} \mathrm{Co}\left(\mathrm{H}_{2} \mathrm{O}\right)_{2} \\
\text { (iiic } \mathrm{M}_{1} \text { ) }\end{array}$ & 285 & 376 & 490 & 4.68 \\
\hline $\begin{array}{l}\mathrm{C}_{27} \mathrm{H}_{22} \mathrm{~N}_{2} \mathrm{O}_{4} \mathrm{Ni}\left(\mathrm{H}_{2} \mathrm{O}\right)_{2} \\
\text { (iiic } \mathrm{M}_{2} \text { ) }\end{array}$ & 273 & 382 & 485 & 3.45 \\
\hline $\begin{array}{l}\mathrm{C}_{27} \mathrm{H}_{22} \mathrm{~N}_{2} \mathrm{O}_{4} \mathrm{Zn}\left(\mathrm{H}_{2} \mathrm{O}\right)_{2} \\
\text { (iiic } \mathrm{M}_{3} \text { ) }\end{array}$ & 288 & 387 & ---- & ---- \\
\hline $\begin{array}{l}\mathrm{C}_{27} \mathrm{H}_{22} \mathrm{~N}_{2} \mathrm{O}_{4} \mathrm{Cd}\left(\mathrm{H}_{2} \mathrm{O}\right)_{2} \\
\text { (iiic } \mathrm{M}_{4} \text { ) }\end{array}$ & 285 & 389 & ---- & ---- \\
\hline $\begin{array}{c}\mathrm{C}_{27} \mathrm{H}_{22} \mathrm{~N}_{2} \mathrm{O}_{4} \mathrm{Cu}\left(\mathrm{H}_{2} \mathrm{O}\right)_{2} \\
\text { (iiic } \mathrm{M}_{5} \text { ) }\end{array}$ & 287 & 377 & 479 & 1.91 \\
\hline $\begin{array}{c}\mathrm{C}_{32} \mathrm{H}_{28} \mathrm{~N}_{2} \mathrm{O}_{6} \\
\text { (iv) }\end{array}$ & 299 & 394 & ---- & ---- \\
\hline $\begin{array}{c}\mathrm{C}_{32} \mathrm{H}_{30} \mathrm{~N}_{2} \mathrm{O}_{8} \mathrm{Co}\left(\mathrm{H}_{2} \mathrm{O}\right)_{2} \\
\left(\mathrm{v} \mathrm{M}_{6}\right)\end{array}$ & 295 & 386 & 518 & 4.87 \\
\hline $\begin{array}{c}\mathrm{C}_{32} \mathrm{H}_{30} \mathrm{~N}_{2} \mathrm{O}_{8} \mathrm{Ni}\left(\mathrm{H}_{2} \mathrm{O}\right)_{2} \\
\left(\mathrm{v} \mathrm{M}_{7}\right)\end{array}$ & 288 & 372 & 510 & 3.39 \\
\hline $\begin{array}{c}\mathrm{C}_{32} \mathrm{H}_{30} \mathrm{~N}_{2} \mathrm{O}_{8} \mathrm{Zn}\left(\mathrm{H}_{2} \mathrm{O}\right)_{2} \\
\left(\mathrm{v} \mathrm{M}_{8}\right)\end{array}$ & 293 & 360 & ---- & ---- \\
\hline $\begin{array}{c}\mathrm{C}_{32} \mathrm{H}_{30} \mathrm{~N}_{2} \mathrm{O}_{8} \mathrm{Cd}\left(\mathrm{H}_{2} \mathrm{O}\right)_{2} \\
\left(\mathrm{v} \mathrm{M}_{9}\right)\end{array}$ & 278 & 374 & ---- & $\begin{array}{l}--- \\
\end{array}$ \\
\hline
\end{tabular}


$\mathrm{C}_{32} \mathrm{H}_{30} \mathrm{~N}_{2} \mathrm{O}_{8} \mathrm{Cu}\left(\mathrm{H}_{2} \mathrm{O}\right)_{2}$ $\left(\mathrm{v} \mathrm{M}_{10}\right)$

\section{6}

380
517

1.98

$\mathrm{Zn}$ and $\mathrm{Cd}(\mathrm{II})$ ion with $\mathrm{d}^{10}$ electronic configuration permits a wide range of symmetries and coordination numbers. Since $\mathrm{d}^{10}$ configuration affords no crystal field stabilization, the stereochemistry of a particular compound depends on the size and polarizing power of the M(II) cation and the steric requirement of the ligands and have no $d-d$ transition and are diamagnetic. The electronic spectra of complexes reveal a charge transfer bands $\pi-\pi$ and $n-\pi$ transitions in the vicinity of the Schiff base ligand at 288, 285 and 293, $278 \mathrm{~nm}$ for both complexes; and 387, 389 and $360,374 \mathrm{~cm}^{-1}$, respectively suggesting an octahedral structure which is common for $\mathrm{d}^{10}$ systems.

\section{HNMR spectra:-}

The NMR spectra of Schiff bases were recorded in dimethyl sulfoxide (DMSO) solution, using tetramethylsilane (TMS) as an internal standard. Chemical shifts were reported as $\delta$-values in parts per million (ppm) relative to $\mathrm{Si}$ $\left(\mathrm{CH}_{3}\right)_{4}$ as relative reference $(\delta=0 \mathrm{ppm})$ and to the solvent as internal reference.

The formation of the complex iiic $\mathbf{M}_{\mathbf{3}}$ from its ligand (iiib) is shown in Figure $\mathbf{1}$ and $\mathbf{2}$.

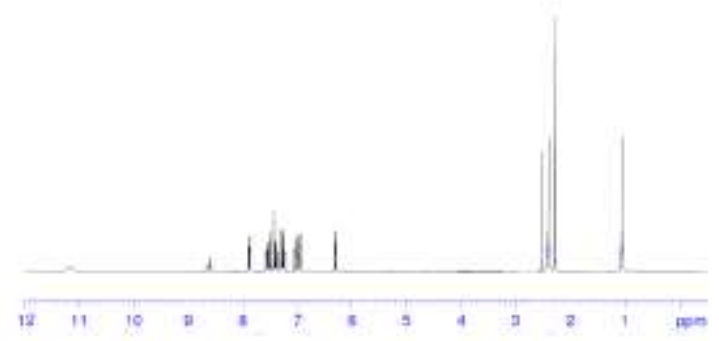

Figure 1: (iiib)

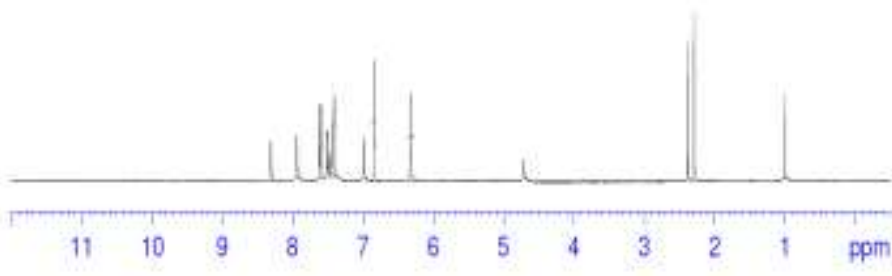

Figure 2: iiic $\mathbf{M}_{3}$

The proton NMR spectrum shows a singlet peaks at 1.03 and $1.01,1.02(3 \mathrm{H}) \mathrm{ppm}$, which corresponds to the [N=C$\mathrm{CH}_{3}$ ] group of the ligand iiib and its $\mathrm{Zn}$ (II) iiic $\mathbf{M}_{3}$ and $\mathrm{Cd}$ (II) iiic $\mathbf{M}_{\mathbf{4}}$ complexes. The singlet peaks of methyl protons (coumarin) appeared at 2.34 and 2.22, $2.20 \mathrm{ppm}$ in the ${ }^{1} \mathrm{H}$ NMR spectra of the ligand iiib and its $\mathrm{Zn}$ (II) iiic $\mathbf{M}_{3}$ and $\mathrm{Cd}(\mathrm{II})$ iiic $\mathbf{M}_{\mathbf{4}}$ complexes respectively. The singlet peaks of aromatic methyl protons appeared at 2.56 and 2.37, $2.33 \mathrm{ppm}$ in the ${ }^{1} \mathrm{H}$ NMR spectra of the ligand iiib and its $\mathrm{Zn}(\mathrm{II})$ iiic $\mathbf{M}_{\mathbf{3}}$ and $\mathrm{Cd}(\mathrm{II})$ iiic $\mathbf{M}_{\mathbf{4}}$ complexes respectively. The two singlet peaks of protons (coumarin) appeared at 6.38, 7.95 (iiib) and 6.32, 7.85(iiic $\mathbf{M}_{3}$ ), 6.18, 7.78 (iiic $\mathbf{M}_{4}$ ) $\mathrm{ppm}$ in the ${ }^{1} \mathrm{H}$ NMR spectra of the ligand and its $\mathrm{Zn}$ (II) and $\mathrm{Cd}(\mathrm{II})$ complexes respectively. The doublet peaks of aromatic protons appeared at 6.96 and 6.80, $6.81 \mathrm{ppm}$ in the ${ }^{1} \mathrm{H}$ NMR spectra of the ligand iiib and its $\mathrm{Zn}(\mathrm{II})$ iiic $\mathbf{M}_{3}$ and $\mathrm{Cd}(\mathrm{II})$ iiicM $\mathbf{4}_{\mathbf{4}}$ complexes respectively. The singlet peaks of aromatic proton appeared at 7.07 and 7.00, $7.01 \mathrm{ppm}$ in the ${ }^{1} \mathrm{H}$ NMR spectra of the ligand iiib and its $\mathrm{Zn}(\mathrm{II})$ iiic $\mathbf{M}_{\mathbf{3}}$ and $\mathrm{Cd}(\mathrm{II})$ iiic $\mathbf{M}_{\mathbf{4}}$ complexes respectively.

Both the ligand and complexes show a group of multipletat 7.3-7.4(4H) iiib, 7.4-7.5(4H) iiic $\mathbf{M}_{3}$ and 7.2-7.3(4H) iiic $\mathbf{M}_{4}$ for aromatic protons respectively. The singlet peaks at 8.67 and $8.27,8.58(\mathrm{H}) \mathrm{ppm}$ which corresponds to the $[\mathrm{N}=\mathrm{C}-\mathrm{H}]$ group of ligand iiib and its $\mathrm{Zn}(\mathrm{II})$ iiic $\mathbf{M}_{3}$ and $\mathrm{Cd}(\mathrm{II})$ iiic $\mathbf{M}_{4}$ complexes. The proton NMR spectrum shows two phenolic-OH groups at $11.27 \mathrm{ppm}$ which are absent in the spectra of $\mathrm{M}(\mathrm{II})$ complexes. This indicates that the deprotonated phenolic-O atom is involved in chelation.

The proton NMR spectrum shows a singlet peaks at 1.05 and $1.00,1.01(6 \mathrm{H}) \mathrm{ppm}$, which corresponds to the [N=C$\mathrm{CH}_{3}$ ] group of ligand iv and its $\mathrm{Zn}(\mathrm{II}) \mathbf{v} \mathbf{M}_{\mathbf{8}}$ and $\mathrm{Cd}(\mathrm{II}) \mathbf{v} \mathbf{M}_{\mathbf{9}}$ complexes. The singlet peaks of four methyl protons (coumarin) appeared at 2.45, 2.54(iv) and 2.27, $2.47\left(\mathbf{v ~ M}_{\mathbf{8}}\right), 2.29,2.47\left(\mathbf{v} \mathbf{M}_{\mathbf{9}}\right) \mathrm{ppm}$ in the ${ }^{1} \mathrm{H}$ NMR spectra of the ligand and its $\mathrm{Zn}(\mathrm{II})$ and $\mathrm{Cd}$ (II) complexes respectively. The singlet peaks of four protons (coumarin) appeared at 6.23, 7.92 (iv) and 6.17, $7.87\left(\mathbf{v} \mathbf{M}_{\mathbf{8}}\right), 6.20,7.89\left(\mathbf{v ~ M}_{\mathbf{9}}\right) \mathrm{ppm}$ in the ${ }^{1} \mathrm{H}-\mathrm{NMR}$ spectra of the ligand and its $\mathrm{Zn}$ (II) and $\mathrm{Cd}$ (II) complexes respectively. Both the ligand and complexes show a group of multipletat 7.32-7.39(4H) iv, 7.25$7.35(4 \mathrm{H}) \mathbf{v} \mathbf{M}_{\mathbf{8}}$ and $7.23-7.38(4 \mathrm{H}) \mathbf{v} \mathbf{M}_{\mathbf{9}}$ for aromatic protons respectively.

The proton NMR spectrum shows two phenolic-OH groups at $10.40 \mathrm{ppm}$ which are absent in the spectra of $\mathrm{M}$ (II) complexes. This indicates that the deprotonated phenolic-O atom is involved in chelation. 
The chemical shift data of the ligands and their metal complexes are presented in Table 6 and 7.

Table 6 :-H NMR spectral data of Schiff base ligands and their metal complexes:

\begin{tabular}{|c|c|c|c|c|c|c|c|c|c|c|c|}
\hline Compound & $\begin{array}{c}\boldsymbol{\delta} \\
(\mathbf{N}=\mathrm{C}- \\
\left.\mathrm{CH}_{3}\right)\end{array}$ & $\begin{array}{c}\delta \\
\left(\mathrm{Cou}_{-}\right. \\
\left.\mathrm{CH}_{3}\right)\end{array}$ & $\begin{array}{c}\delta \\
(\mathrm{Ar}- \\
\left.\mathrm{CH}_{3}\right)\end{array}$ & $\begin{array}{c}\boldsymbol{\delta} \\
\left(\mathbf{H}_{2} \mathbf{O}\right)\end{array}$ & $\begin{array}{c}\boldsymbol{\delta} \\
(\mathbf{C o u}- \\
\mathbf{H})\end{array}$ & $\begin{array}{c}\boldsymbol{\delta} \\
(\mathbf{A r}- \\
\mathbf{H}) \\
\end{array}$ & $\begin{array}{c}\boldsymbol{\delta} \\
(\mathbf{A r}- \\
\mathbf{H})\end{array}$ & $\begin{array}{c}\boldsymbol{\delta} \\
(\mathbf{A r}- \\
\mathbf{H}) \\
\end{array}$ & $\begin{array}{c}\boldsymbol{\delta} \\
(\text { Cou- } \\
\text { H) }\end{array}$ & $\begin{array}{c}\boldsymbol{\delta} \\
(\mathrm{N}=\mathrm{C}- \\
\mathbf{H})\end{array}$ & $\begin{array}{c}\delta(\mathbf{O}- \\
\mathbf{H})\end{array}$ \\
\hline $\begin{array}{l}\mathrm{C}_{27} \mathrm{H}_{24} \mathrm{~N}_{2} \mathrm{O}_{4} \\
\text { (iiiib }\end{array}$ & 1.03 & 2.34 & 2.56 & - & 6.38 & 6.96 & 7.07 & $\begin{array}{l}7.3- \\
7.4\end{array}$ & 7.95 & 8.67 & 11.27 \\
\hline $\begin{array}{c}\mathrm{C}_{27} \mathrm{H}_{22} \mathrm{~N}_{2} \mathrm{O}_{4} \mathrm{Zn}\left(\mathrm{H}_{2} \mathrm{O}\right)_{2} \\
\text { (iiic } \mathrm{M}_{3} \text { ) }\end{array}$ & 1.01 & 2.22 & 2.37 & 4.72 & 6.32 & 6.80 & 7.00 & $\begin{array}{l}7.4- \\
7.5\end{array}$ & 7.85 & 8.27 & - \\
\hline $\begin{array}{c}\mathrm{C}_{27} \mathrm{H}_{22} \mathrm{~N}_{2} \mathrm{O}_{4} \mathrm{Cd}\left(\mathrm{H}_{2} \mathrm{O}\right)_{2} \\
\text { (iiic } \mathrm{M}_{4} \text { ) }\end{array}$ & 1.02 & 2.20 & 2.33 & 4.54 & 6.18 & 6.81 & 7.01 & $\begin{array}{l}7.2- \\
7.3 \\
\end{array}$ & 7.78 & 8.58 & - \\
\hline
\end{tabular}

Table 7:- ${ }^{1} \mathrm{H}$ NMR spectral data of Schiff base ligands and their metal complexes:

\begin{tabular}{|c|c|c|c|c|c|c|c|c|}
\hline $\begin{array}{c}\text { Compound } \\
\mathrm{C}_{32} \mathrm{H}_{28} \mathrm{~N}_{2} \mathrm{O}_{6} \\
(\mathbf{i v})\end{array}$ & $\begin{array}{c}\boldsymbol{\delta} \\
(\mathbf{N = C}- \\
\mathbf{C H}\end{array}$ & $\begin{array}{c}\boldsymbol{\delta} \\
(\mathbf{C o u}- \\
\left.\mathbf{C H}_{3}\right)\end{array}$ & $\begin{array}{c}\boldsymbol{\delta} \\
(\mathbf{A r}- \\
\left.\mathbf{C H}_{3}\right)\end{array}$ & $\boldsymbol{\delta}\left(\mathbf{H}_{\mathbf{2}} \mathbf{O}\right)$ & $\begin{array}{c}\boldsymbol{\delta}(\mathbf{C o u}- \\
\mathbf{H})\end{array}$ & $\begin{array}{c}\boldsymbol{\delta} \\
(\mathbf{A r}-\mathbf{H})\end{array}$ & $\begin{array}{c}\boldsymbol{\delta} \\
(\mathbf{C o u}- \\
\mathbf{H})\end{array}$ & $\begin{array}{c}\boldsymbol{\delta} \\
(\mathbf{O}-\mathbf{H})\end{array}$ \\
\hline $\begin{array}{c}\mathrm{C}_{32} \mathrm{H}_{30} \mathrm{~N}_{2} \mathrm{O}_{8} \mathrm{Zn}\left(\mathrm{H}_{2} \mathrm{O}\right)_{2} \\
\left(\mathrm{v} \mathrm{M}_{8}\right)\end{array}$ & 1.00 & 2.45 & 2.54 & - & 6.23 & $7.32-$ & 7.92 & 10.40 \\
\hline $\begin{array}{c}\mathrm{C}_{32} \mathrm{H}_{30} \mathrm{~N}_{2} \mathrm{O}_{8} \mathrm{Cd}\left(\mathrm{H}_{2} \mathrm{O}\right)_{2} \\
\left(\mathrm{v} \mathrm{M}_{9}\right)\end{array}$ & 1.01 & 2.29 & 2.47 & 4.51 & 6.17 & $\begin{array}{c}7.25- \\
7.35\end{array}$ & 7.87 & - \\
\hline
\end{tabular}

\section{Mass spectral studies:-}

The mass spectra of Schiff base ligands (iiib, iv) exhibited parent peaks due to molecular ions $\left(\mathrm{M}^{+}\right)$. The proposed molecular formula of these complexes was confirmed by comparing their molecular formula weights with $\mathrm{m} / \mathrm{z}$ values. The mass spectrum for the Schiff base ligands iiib and iv (Figure 3) showed a molecular ion peak at $\mathrm{m} / \mathrm{z}=$ 440,536 respectively.

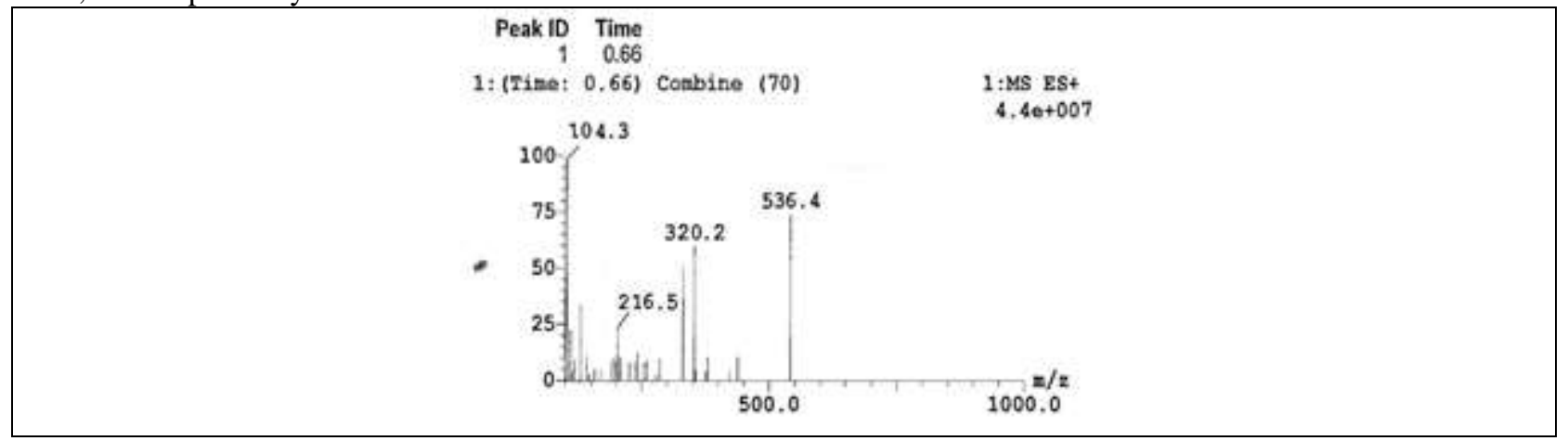

Figure 3:-Mass spectrum of ligand ligand di[1,2-7-hydroxy-6-(1-imino-ethyl)]-4,8-dimethyl-chromen-2one]benzene(iv):

Thermal analysis:-

In the present investigation, heating rates were suitably controlled at $10^{\circ} \mathrm{C} \mathrm{min}^{-1}$ under nitrogen atmosphere, and the weight loss was measured from the ambient temperature up to $800^{\circ} \mathrm{C}$. The data are provided in Table 8. The TGA and DTG curve of complex iiic $\mathbf{M}_{\mathbf{1}}$ is given in Figure 4.The weight loss for each chelate was calculated within the corresponding temperature ranges.

The stages of decomposition, temperature range, decomposition products as well as observed and calculated mass loss percentages of all the complexes are illustrated in table 8. 
Table 8:-Stepwise thermal degradation data obtained from TGA curves and their composition.

\begin{tabular}{|c|c|c|c|c|c|c|c|c|c|}
\hline \multirow[b]{2}{*}{ Complex } & \multirow[b]{2}{*}{ Process } & \multirow{2}{*}{$\begin{array}{l}\text { Temp. } \\
\text { range } \\
\left({ }^{\circ} \mathrm{C}\right)\end{array}$} & \multirow{2}{*}{$\begin{array}{l}\text { Degra- } \\
\text { dation } \\
\text { Products }\end{array}$} & \multicolumn{2}{|c|}{$\begin{array}{c}\% \text { Weight } \\
\text { loss }\end{array}$} & \multirow[t]{2}{*}{$\begin{array}{l}\text { No. of } \\
\text { Moles }\end{array}$} & \multicolumn{2}{|c|}{$\%$ Residue } & \multirow[b]{2}{*}{ Nature } \\
\hline & & & & Calcd & Expt & & Calcd & Expt & \\
\hline $\mathrm{C}_{27} \mathrm{H}_{22} \mathrm{~N}_{2} \mathrm{O}_{4} \mathrm{Co}\left(\mathrm{H}_{2} \mathrm{O}\right)_{2}$ & I & $120-180$ & $\mathrm{H}_{2} \mathrm{O}$ & 5.5 & 5.8 & 2 & 12.10 & 10.7 & $\mathrm{CoO}$ \\
\hline (iiic $\mathrm{M}_{1}$ ) & II & $185-340$ & Ligand & 82.4 & 83.5 & 1 & & & \\
\hline $\mathrm{C}_{27} \mathrm{H}_{22} \mathrm{~N}_{2} \mathrm{O}_{4} \mathrm{Ni}\left(\mathrm{H}_{2} \mathrm{O}\right)_{2}$ & $\mathrm{I}$ & $80-170$ & $\mathrm{H}_{2} \mathrm{O}$ & 5.5 & 6.4 & 2 & 12.4 & 10.47 & $\mathrm{NiO}$ \\
\hline (iiic $\mathrm{M}_{2}$ ) & II & $175-330$ & Ligand & 82.08 & 83.45 & 1 & & & \\
\hline $\mathrm{C}_{27} \mathrm{H}_{22} \mathrm{~N}_{2} \mathrm{O}_{4} \mathrm{Zn}\left(\mathrm{H}_{2} \mathrm{O}\right)_{2}$ & $\mathrm{I}$ & $115-156$ & $\mathrm{H}_{2} \mathrm{O}$ & 5.4 & 5.8 & 2 & 8.00 & 8.70 & $\mathrm{ZnO}$ \\
\hline (iiic $\mathrm{M}_{3}$ ) & II & 290-398 & Ligand & 86.6 & 85.5 & 1 & & & \\
\hline $\mathrm{C}_{27} \mathrm{H}_{22} \mathrm{~N}_{2} \mathrm{O}_{4} \mathrm{Cd}\left(\mathrm{H}_{2} \mathrm{O}\right)_{2}$ & $\mathrm{I}$ & $110-185$ & $\mathrm{H}_{2} \mathrm{O}$ & 4.6 & 5.10 & 2 & 20.10 & 20.34 & $\mathrm{CdO}$ \\
\hline (iiic $\mathrm{M}_{4}$ ) & II & $250-480$ & Ligand & 74.82 & 74.56 & 1 & & & \\
\hline $\mathrm{C}_{27} \mathrm{H}_{22} \mathrm{~N}_{2} \mathrm{O}_{4} \mathrm{Cu}\left(\mathrm{H}_{2} \mathrm{O}\right)_{2}$ & I & $157-230$ & $\mathrm{H}_{2} \mathrm{O}$ & 5.4 & 6.3 & 2 & 7.7 & 8.2 & $\mathrm{CuO}$ \\
\hline (iiic $\mathrm{M}_{5}$ ) & II & $270-420$ & Ligand & 86.9 & 85.5 & 1 & & & \\
\hline $\mathrm{C}_{32} \mathrm{H}_{30} \mathrm{~N}_{2} \mathrm{O}_{8} \mathrm{Co}\left(\mathrm{H}_{2} \mathrm{O}\right)_{2}$ & I & $100-170$ & $\mathrm{H}_{2} \mathrm{O}$ & 5.71 & 6.02 & 2 & 9.22 & 9.98 & $\mathrm{CoO}$ \\
\hline$\left(\mathrm{v} \mathrm{M}_{6}\right)$ & II & $180-320$ & Ligand & 85.07 & 84.0 & 1 & & & \\
\hline $\mathrm{C}_{32} \mathrm{H}_{30} \mathrm{~N}_{2} \mathrm{O}_{8} \mathrm{Ni}\left(\mathrm{H}_{2} \mathrm{O}\right)_{2}$ & $\mathrm{I}$ & $125-160$ & $\mathrm{H}_{2} \mathrm{O}$ & 5.61 & 6.50 & 2 & 9.37 & 9.00 & $\mathrm{NiO}$ \\
\hline$\left(\mathrm{v} \mathrm{M}_{7}\right)$ & II & $265-450$ & Ligand & 85.02 & 84.50 & 1 & & & \\
\hline $\mathrm{C}_{32} \mathrm{H}_{30} \mathrm{~N}_{2} \mathrm{O}_{8} \mathrm{Zn}\left(\mathrm{H}_{2} \mathrm{O}\right)_{2}$ & $\mathrm{I}$ & $150-210$ & $\mathrm{H}_{2} \mathrm{O}$ & 5.66 & 5.51 & 2 & 10.07 & 10.49 & $\mathrm{ZnO}$ \\
\hline$\left(\mathrm{v} \mathrm{M}_{8}\right)$ & II & $295-520$ & Ligand & 84.27 & 84.0 & 1 & & & \\
\hline $\mathrm{C}_{32} \mathrm{H}_{30} \mathrm{~N}_{2} \mathrm{O}_{8} \mathrm{Cd}\left(\mathrm{H}_{2} \mathrm{O}\right)_{2}$ & $\mathrm{I}$ & $110-180$ & $\mathrm{H}_{2} \mathrm{O}$ & 6.71 & 6.50 & 2 & 14.7 & 15.15 & $\mathrm{CdO}$ \\
\hline$\left(\mathrm{v} \mathrm{M}_{9}\right)$ & II & $280-445$ & Ligand & 78.59 & 78.35 & 1 & & & \\
\hline $\mathrm{C}_{32} \mathrm{H}_{30} \mathrm{~N}_{2} \mathrm{O}_{8} \mathrm{Cu}\left(\mathrm{H}_{2} \mathrm{O}\right)_{2}$ & I & $155-205$ & $\mathrm{H}_{2} \mathrm{O}$ & 5.67 & 5.00 & 2 & 9.79 & 11.50 & $\mathrm{CuO}$ \\
\hline$\left(\mathrm{v} \mathrm{M}_{10}\right)$ & II & $270-430$ & Ligand & 84.54 & 83.50 & 1 & & & \\
\hline
\end{tabular}




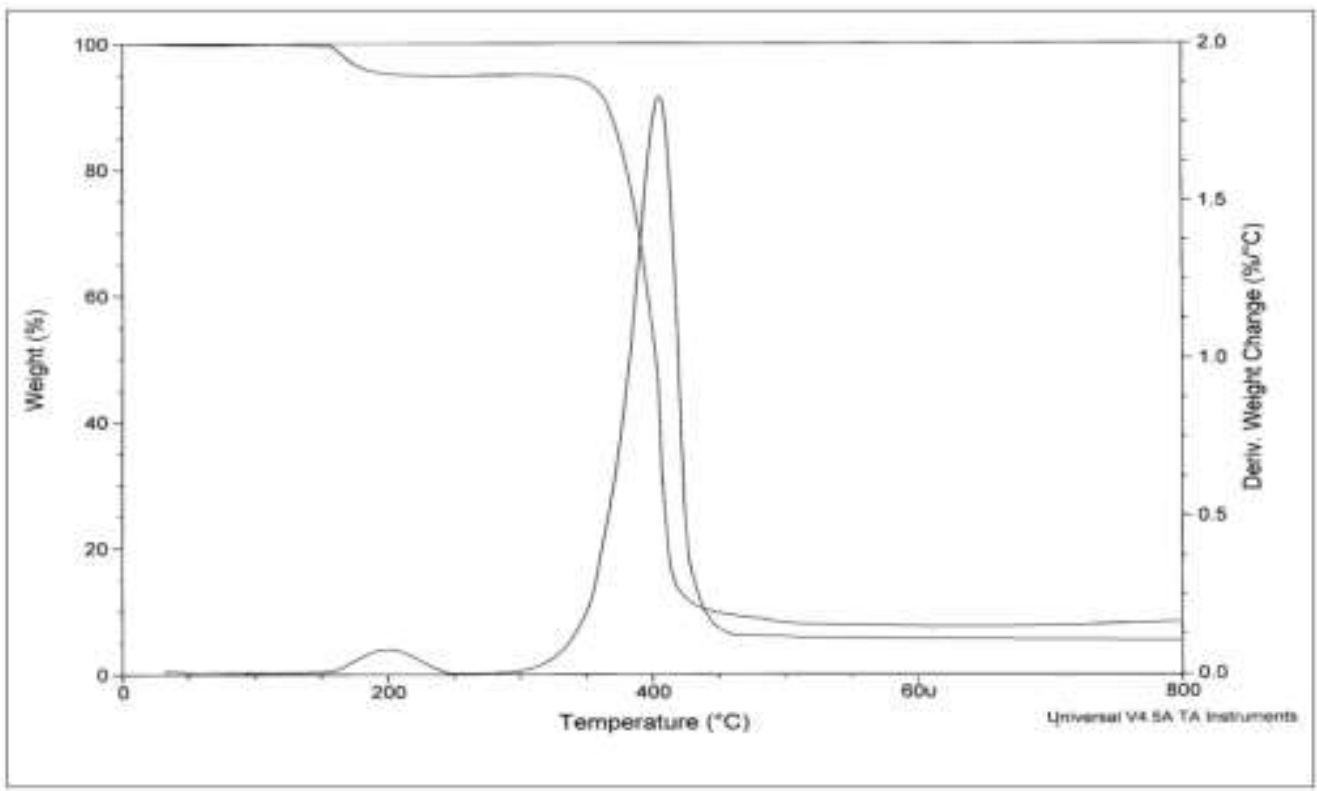

Figure 4:-TG curves of cobalt complex of 7-hydroxy-6-(1-\{2-[(2-hydroxy-5-methyl-benzylidene)-amino]phenylimino]-ethyl)-4,8-dimethyl-chromen-2-one (iiic $\mathrm{M}_{1}$ )

\section{Racah parameters:-}

For the octahedral complexes the ligand field parameters $D q, B$ and $C$ were found (Table 9) by solving the secular equation and possible to simplify the problem to that of solving a quadratic equation in $D q, v_{1}, v_{2}, v_{3}$ and $v_{4}$ only. These parameters indicate the significant covalent character of the metal ligand bonds.

Table9:- Ligand field parameters of Schiff base complexes.

\begin{tabular}{|c|c|c|c|c|}
\hline Complex & $\lambda_{\max }(\mathrm{nm})$ & Dq (nm) & B (nm) & $\mathrm{C}(\mathrm{nm})$ \\
\hline $\begin{array}{c}\mathrm{C}_{27} \mathrm{H}_{22} \mathrm{~N}_{2} \mathrm{O}_{4} \mathrm{Co}\left(\mathrm{H}_{2} \mathrm{O}\right)_{2} \\
\text { (iiic } \mathrm{M}_{1} \text { ) }\end{array}$ & $270,325,430$ & 27.0 & 44.9 & ---- \\
\hline $\begin{array}{c}\mathrm{C}_{27} \mathrm{H}_{22} \mathrm{~N}_{2} \mathrm{O}_{4} \mathrm{Ni}\left(\mathrm{H}_{2} \mathrm{O}\right)_{2} \\
\text { (iiic } \mathrm{M}_{2} \text { ) }\end{array}$ & $330,380,420,470$ & 33.0 & 46.53 & 78.0 \\
\hline $\begin{array}{c}\mathrm{C}_{27} \mathrm{H}_{22} \mathrm{~N}_{2} \mathrm{O}_{4} \mathrm{Cu}\left(\mathrm{H}_{2} \mathrm{O}\right)_{2} \\
\text { (iiic } \mathbf{M}_{5} \text { ) }\end{array}$ & $310,350,460$ & 31.0 & 47.8 & ---- \\
\hline $\begin{array}{c}\mathrm{C}_{32} \mathrm{H}_{30} \mathrm{~N}_{2} \mathrm{O}_{8} \mathrm{Co}\left(\mathrm{H}_{2} \mathrm{O}\right)_{2} \\
\left(\mathrm{v} \mathrm{M}_{6}\right)\end{array}$ & $280,340,460$ & 28.0 & 47.73 & ---- \\
\hline $\begin{array}{c}\mathrm{C}_{32} \mathrm{H}_{30} \mathrm{~N}_{2} \mathrm{O}_{8} \mathrm{Ni}\left(\mathrm{H}_{2} \mathrm{O}\right)_{2} \\
\left(\mathrm{v} \mathrm{M}_{7}\right)\end{array}$ & $380,390,460,480$ & 38.0 & 49.00 & 81.0 \\
\hline 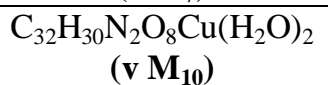 & $350,430,490$ & 35.0 & 54.3 & ---- \\
\hline
\end{tabular}

\section{Biology:-}

The antimicrobial screenings of the synthesized compounds were undertaken using disc diffusion method. The screening results of the tested compounds against the gram positive bacteria, gram negative bacteria in addition to the pathogenic fungi microorganisms are summarized in Table 10-13.

The obtained data revealed that most of the compounds showed moderate to excellent activities against the tested microorganisms. Complexes ivM $\mathbf{M}_{1}, \mathbf{i v} \mathbf{M}_{3}, \mathbf{i v} \mathbf{M}_{\mathbf{9}}, \mathbf{i v} \mathbf{M}_{2}, \mathbf{i v} \mathbf{M}_{\mathbf{4}}$ and $\mathbf{i v} \mathbf{M}_{\mathbf{1 0}}$ were shown maximum zone of inhibition in both the bacterial and fungal strains compared to remaining compounds in the series with respect to standard Streptomycin and Ciprofloxacin in the case of bacterial, Fluconazole and Ketoconazole with respect to fungal strains. A comparative study of ligand and their metal complexes indicates that some of the metal chelates exhibits higher antimicrobial activity than the free ligands. The increase in antimicrobial activity of metal chelates is due to the presence of metal ion in the complexes. 
Table10:-In-vitro antibacterial activity of compounds ivM $M_{1}-$ ivM $_{10}$

\begin{tabular}{|c|c|c|c|c|c|c|c|c|}
\hline \multirow{3}{*}{ Compound } & \multicolumn{8}{|c|}{ Zone of inhibition in $\mathrm{mm}$} \\
\hline & \multicolumn{4}{|c|}{ Gram positive bacteria } & \multicolumn{4}{|c|}{ Gram negative bacteria } \\
\hline & $\begin{array}{c}\text { M. } \\
\text { luteu } \\
\text { S }\end{array}$ & $\begin{array}{c}\text { S. } \\
\text { aureus(MRS } \\
\text { A) }\end{array}$ & $\begin{array}{c}\text { S. } \\
\text { aureu } \\
\text { s }\end{array}$ & $\begin{array}{c}\text { E. } \\
\text { erogen } \\
\text { es }\end{array}$ & $\begin{array}{c}\text { S. } \\
\text { typhimuriu } \\
m\end{array}$ & $\begin{array}{c}\text { S. } \\
\text { Paratyph } \\
\text { i-B }\end{array}$ & $\begin{array}{c}\text { P. } \\
\text { vulgar } \\
\text { is }\end{array}$ & $\begin{array}{c}\text { K. } \\
\text { pneumon } \\
\text { ia }\end{array}$ \\
\hline $\begin{array}{c}\mathrm{C}_{31} \mathrm{H}_{30} \mathbf{N}_{2} \mathrm{O}_{2} \\
\text { (iiia) }\end{array}$ & 9 & 8 & 9 & 10 & 8 & 8 & 10 & 9 \\
\hline $\begin{array}{c}\mathrm{C}_{31} \mathrm{H}_{28} \mathrm{~N}_{2} \mathrm{O}_{2} \mathrm{Co}\left(\mathrm{H}_{2} \mathrm{O}\right)_{2} \\
\left(\mathrm{ivM}_{1}\right)\end{array}$ & 23 & 23 & 21 & 21 & 15 & 15 & 15 & 24 \\
\hline $\begin{array}{c}\mathrm{C}_{31} \mathrm{H}_{28} \mathrm{~N}_{2} \mathrm{O}_{2} \mathrm{Ni}\left(\mathrm{H}_{2} \mathrm{O}\right)_{2} \\
\left(\mathrm{ivM}_{3}\right)\end{array}$ & 15 & 12 & 23 & 21 & 15 & 13 & 73 & 17 \\
\hline $\begin{array}{c}\mathrm{C}_{31} \mathrm{H}_{28} \mathrm{~N}_{2} \mathrm{O}_{2} \mathrm{Zn}\left(\mathrm{H}_{2} \mathrm{O}\right)_{2} \\
\left(\mathrm{ivM}_{5}\right)\end{array}$ & 14 & 15 & 13 & 17 & 11 & 14 & 11 & 8 \\
\hline $\begin{array}{c}\mathrm{C}_{31} \mathrm{H}_{28} \mathrm{~N}_{2} \mathrm{O}_{2} \mathrm{Cd}\left(\mathrm{H}_{2} \mathrm{O}\right)_{2} \\
\left(\mathrm{ivM}_{7}\right)\end{array}$ & 10 & 8 & 8 & 9 & 15 & 9 & 12 & 8 \\
\hline $\begin{array}{c}\mathrm{C}_{31} \mathrm{H}_{28} \mathrm{~N}_{2} \mathrm{O}_{2} \mathrm{Cu}\left(\mathrm{H}_{2} \mathrm{O}\right)_{2} \\
\left(\mathrm{ivM}_{9}\right)\end{array}$ & 21 & 23 & 23 & 21 & 17 & 16 & 21 & 13 \\
\hline $\begin{array}{c}\mathrm{C}_{29} \mathrm{H}_{24} \mathrm{~N}_{2} \mathrm{O}_{2} \mathrm{Cl}_{2} \\
\text { (iiib) }\end{array}$ & 10 & 9 & 8 & 9 & 10 & 10 & 9 & 8 \\
\hline $\begin{array}{c}\mathrm{C}_{29} \mathrm{H}_{22} \mathrm{~N}_{2} \mathrm{O}_{2} \mathrm{Cl}_{2} \mathrm{Co}\left(\mathrm{H}_{2}\right. \\
\mathrm{O})_{2} \\
\left.(\mathrm{ivM})_{2}\right)\end{array}$ & 19 & 23 & 26 & 25 & 24 & 19 & 21 & 21 \\
\hline $\begin{array}{c}\mathrm{C}_{29} \mathrm{H}_{22} \mathrm{~N}_{2} \mathrm{O}_{2} \mathrm{Cl}_{2} \mathrm{Ni}\left(\mathrm{H}_{2}\right. \\
\mathrm{O})_{2} \\
\left.(\mathrm{ivM})_{4}\right)\end{array}$ & 19 & 24 & 25 & 21 & 18 & 19 & 19 & 21 \\
\hline $\begin{array}{c}\mathrm{C}_{29} \mathrm{H}_{22} \mathrm{~N}_{2} \mathrm{O}_{2} \mathrm{Cl}_{2} \mathrm{Zn}\left(\mathrm{H}_{2}\right. \\
\mathrm{O}_{2} \\
\left(\mathrm{ivM}_{6}\right) \\
\end{array}$ & 9 & 16 & 16 & 10 & 10 & 9 & 11 & 12 \\
\hline $\begin{array}{c}\mathrm{C}_{29} \mathrm{H}_{22} \mathrm{~N}_{2} \mathrm{O}_{2} \mathrm{Cl}_{2} \mathrm{Cd}\left(\mathrm{H}_{2}\right. \\
\mathrm{O})_{2} \\
\left.(\mathrm{ivM})_{8}\right)\end{array}$ & 11 & 13 & 18 & 17 & 13 & 14 & 9 & 11 \\
\hline $\begin{array}{c}\mathrm{C}_{29} \mathrm{H}_{22} \mathrm{~N}_{2} \mathrm{O}_{2} \mathrm{Cl}_{2} \mathrm{Cu}\left(\mathrm{H}_{2}\right. \\
\mathrm{O})_{2} \\
\left.(\mathrm{ivM})_{10}\right)\end{array}$ & 21 & 23 & 21 & 23 & 21 & 21 & 21 & 23 \\
\hline Streptomycin & 24 & 23 & 25 & 27 & 26 & 25 & 21 & 24 \\
\hline
\end{tabular}

Table 11:-Minimum inhibitory concentration $(\mu \mathrm{g} / \mathrm{ml})$. 


\begin{tabular}{|c|c|c|c|c|c|c|c|c|}
\hline (ivM9) & & & & & & & & \\
\hline $\begin{array}{c}\mathrm{C}_{29} \mathrm{H}_{22} \mathrm{~N}_{2} \mathrm{O}_{2} \mathrm{Cl}_{2} \mathrm{Co}\left(\mathrm{H}_{2}\right. \\
\mathrm{O}_{2} \\
\left.(\mathrm{ivM})_{2}\right)\end{array}$ & 16.52 & 125 & 62.5 & 62.5 & 30.15 & 125 & 125 & 500 \\
\hline $\begin{array}{c}\mathrm{C}_{29} \mathrm{H}_{22} \mathrm{~N}_{2} \mathrm{O}_{2} \mathrm{Cl}_{2} \mathrm{Ni}\left(\mathrm{H}_{2} \mathrm{O}\right. \\
)_{2} \\
\left(\mathrm{ivM}_{4}\right)\end{array}$ & 125 & 62.5 & 16.52 & 125 & 30.15 & 125 & 62.5 & 16.52 \\
\hline $\begin{array}{c}\mathrm{C}_{29} \mathrm{H}_{22} \mathrm{~N}_{2} \mathrm{O}_{2} \mathrm{Cl}_{2} \mathrm{Cu}\left(\mathrm{H}_{2}\right. \\
\text { O) })_{2} \\
\left(\mathrm{ivM}_{10}\right)\end{array}$ & 30.15 & 16.52 & 16.52 & 62.5 & 16.52 & 125 & 16.52 & 62.5 \\
\hline Streptomycin & 6.25 & $>100$ & 6.25 & 25 & 30 & 6.25 & ni & 6.25 \\
\hline Ciprofloxacin & $<0.78$ & $>100$ & $<0.78$ & $>100$ & $>100$ & $<0.78$ & 6.25 & $<0.78$ \\
\hline
\end{tabular}

Table12:- In-vitro antifungal activity of compounds ivM $\mathbf{M}_{1}-\mathrm{ivM}_{10}$.

\begin{tabular}{|c|c|c|c|c|}
\hline & \multicolumn{4}{|c|}{ Zone of inhibition in mm } \\
\hline Compounds & B. cinerea & C. albicans & M. pachydermatis & C.krusei \\
\hline $\begin{array}{c}\mathrm{C}_{31} \mathrm{H}_{30} \mathbf{N}_{2} \mathrm{O}_{2} \\
\text { (iiia) }\end{array}$ & 8 & 9 & 11 & 10 \\
\hline $\begin{array}{c}\mathrm{C}_{31} \mathrm{H}_{28} \mathrm{~N}_{2} \mathrm{O}_{2} \mathrm{Co}\left(\mathrm{H}_{2} \mathrm{O}\right)_{2} \\
\left(\mathrm{ivM}_{1}\right)\end{array}$ & 16 & 23 & 21 & 16 \\
\hline $\begin{array}{c}\mathrm{C}_{31} \mathrm{H}_{28} \mathrm{~N}_{2} \mathrm{O}_{2} \mathrm{Ni}\left(\mathrm{H}_{2} \mathrm{O}\right)_{2} \\
\left(\mathrm{ivM}_{3}\right)\end{array}$ & 15 & 21 & 24 & 15 \\
\hline $\begin{array}{c}\mathrm{C}_{31} \mathrm{H}_{28} \mathrm{~N}_{2} \mathrm{O}_{2} \mathrm{Zn}\left(\mathrm{H}_{2} \mathrm{O}\right)_{2} \\
\left(\mathrm{ivM}_{5}\right)\end{array}$ & 8 & 10 & 12 & 14 \\
\hline $\begin{array}{c}\mathrm{C}_{31} \mathrm{H}_{28} \mathrm{~N}_{2} \mathrm{O}_{2} \mathrm{Cd}\left(\mathrm{H}_{2} \mathrm{O}\right)_{2} \\
\left(\mathrm{ivM}_{7}\right)\end{array}$ & 11 & 21 & 9 & 14 \\
\hline $\begin{array}{c}\mathrm{C}_{31} \mathrm{H}_{28} \mathrm{~N}_{2} \mathrm{O}_{2} \mathrm{Cu}\left(\mathrm{H}_{2} \mathrm{O}\right)_{2} \\
(\text { (ivM }\end{array}$ & 13 & 20 & 19 & 13 \\
\hline $\begin{array}{c}\mathrm{C}_{29} \mathrm{H}_{24} \mathrm{~N}_{2} \mathrm{O}_{2} \mathrm{Cl}_{2} \\
\text { (iiib) }\end{array}$ & 8 & 8 & 9 & 10 \\
\hline $\begin{array}{c}\mathrm{C}_{29} \mathrm{H}_{22} \mathrm{~N}_{2} \mathrm{O}_{2} \mathrm{Cl}_{2} \mathrm{Co}\left(\mathrm{H}_{2} \mathrm{O}\right)_{2} \\
\left(\mathrm{ivM}_{2}\right)\end{array}$ & 16 & 23 & 23 & 17 \\
\hline $\begin{array}{c}\mathrm{C}_{29} \mathrm{H}_{22} \mathrm{~N}_{2} \mathrm{O}_{2} \mathrm{Cl}_{2} \mathrm{Ni}\left(\mathrm{H}_{2} \mathrm{O}\right)_{2} \\
\left(\mathrm{ivM}_{4}\right)\end{array}$ & 13 & 22 & 24 & 18 \\
\hline $\begin{array}{c}\mathrm{C}_{29} \mathrm{H}_{22} \mathrm{~N}_{2} \mathrm{O}_{2} \mathrm{Cl}_{2} \mathrm{Zn}\left(\mathrm{H}_{2} \mathrm{O}\right)_{2} \\
\left(\mathrm{ivM}_{6}\right)\end{array}$ & 13 & 15 & 10 & 11 \\
\hline $\begin{array}{c}\mathrm{C}_{29} \mathrm{H}_{22} \mathrm{~N}_{2} \mathrm{O}_{2} \mathrm{Cl}_{2} \mathrm{Cd}\left(\mathrm{H}_{2} \mathrm{O}\right)_{2} \\
\left(\mathrm{ivM} M_{8}\right)\end{array}$ & 8 & 10 & 11 & 12 \\
\hline $\begin{array}{c}\mathrm{C}_{29} \mathrm{H}_{22} \mathrm{~N}_{2} \mathrm{O}_{2} \mathrm{Cl}_{2} \mathrm{Cu}\left(\mathrm{H}_{2} \mathrm{O}\right)_{2} \\
\left(\text { ivM M }_{10}\right)\end{array}$ & 15 & 22 & 20 & 18 \\
\hline Ketoconazole & 17 & 24 & 25 & 19 \\
\hline
\end{tabular}

Table13:-MIC (mg/ml) of compounds against tested fungi.

\begin{tabular}{|c|c|c|c|c|}
\hline \multirow[b]{2}{*}{ Compounds } & \multicolumn{4}{|c|}{ Minimum inhibitory concentration $(\mu \mathrm{g} / \mathrm{ml})$} \\
\hline & $\begin{array}{c}\text { B. } \\
\text { cinerea }\end{array}$ & C. albicans & M. pachydermatis & $\underset{\text { krusei }}{\mathrm{C} .}$ \\
\hline $\begin{array}{l}\mathrm{C}_{31} \mathrm{H}_{28} \mathrm{~N}_{2} \mathrm{O}_{2} \mathrm{Co}\left(\mathrm{H}_{2} \mathrm{O}\right)_{2} \\
\quad\left(\mathrm{ivM}_{1}\right)\end{array}$ & 16.52 & 135 & 30.15 & 135 \\
\hline $\begin{array}{c}\mathrm{C}_{31} \mathrm{H}_{28} \mathrm{~N}_{2} \mathrm{O}_{2} \mathrm{Ni}\left(\mathrm{H}_{2} \mathrm{O}\right)_{2} \\
\left(\mathrm{ivM}_{3}\right)\end{array}$ & 60.5 & 135 & 30.15 & 16.52 \\
\hline $\begin{array}{c}\mathrm{C}_{31} \mathrm{H}_{28} \mathrm{~N}_{2} \mathrm{O}_{2} \mathrm{Cu}\left(\mathrm{H}_{2} \mathrm{O}\right)_{2} \\
\left(\mathrm{ivM}_{9}\right)\end{array}$ & 16.52 & 30.15 & 135 & 60.5 \\
\hline
\end{tabular}




\begin{tabular}{|c|c|c|c|c|}
\hline $\begin{array}{c}\mathrm{C}_{29} \mathrm{H}_{22} \mathrm{~N}_{2} \mathrm{O}_{2} \mathrm{Cl}_{2} \mathrm{Co}\left(\mathrm{H}_{2} \mathrm{O}\right)_{2} \\
(\text { ivM }\end{array}$ & 16.52 & 135 & 30.15 & 60.5 \\
\hline $\begin{array}{c}\mathrm{C}_{29} \mathrm{H}_{22} \mathrm{~N}_{2} \mathrm{O}_{2} \mathrm{Cl}_{2} \mathrm{Ni}\left(\mathrm{H}_{2} \mathrm{O}\right)_{2} \\
\left(\mathrm{ivM} \mathrm{M}_{4}\right)\end{array}$ & 135 & 60.5 & 30.15 & 16.52 \\
\hline $\begin{array}{c}\mathrm{C}_{29} \mathrm{H}_{22} \mathrm{~N}_{2} \mathrm{O}_{2} \mathrm{Cl}_{2} \mathrm{Cu}\left(\mathrm{H}_{2} \mathrm{O}\right)_{2} \\
\left(\mathrm{ivM}_{10}\right)\end{array}$ & 16.52 & 30.15 & 60.5 & 60.5 \\
\hline Fluconazole & ni & $>100$ & 13.5 & 13.5 \\
\hline Ketoconazole & 25 & 25 & 15 & 15 \\
\hline
\end{tabular}

Significant MIC values were observed against gram positive; gram negative bacteria and antifungal activity are summarized in Table 10-12. Compounds ivM $\mathbf{M}_{1}, \mathbf{i v} \mathbf{M}_{2}, \mathbf{i v} \mathbf{M}_{5}, \mathbf{i v} \mathbf{M}_{6}, \mathbf{i v} \mathbf{M}_{7}$ and $\mathbf{i v} \mathbf{M}_{10}$ exhibited good MIC result among the series. In comparison, compound $\mathbf{i v} \mathbf{M}_{6}, \mathbf{i v} \mathbf{M}_{\mathbf{7}}$ and $\mathbf{i v} \mathbf{M}_{\mathbf{1 0}}$ with halogen substituted is more potent and showed better activity for most of the tested bacteria and fungi.

\section{Conclusion:-}

A series of metal (II) complexes have been synthesized from the Schiff base. The ligand (iiib, iv) and their complexes (iiic $\mathbf{M}_{\mathbf{1}}-\mathbf{M}_{5}, \mathbf{v} \mathbf{M}_{\mathbf{6}}-\mathbf{M}_{10}$ ) were characterized by analytical and spectral techniques like IR, ${ }^{1} \mathrm{H}$ NMR, UVVIS, elemental analysis, molar electric conductance, magnetic susceptibility and thermal studies. Molar conductance values in DMF indicate the non-electrolytic nature of the complexes. Mass spectral data are in agreement with the structures confirmed by other spectroscopic techniques.

The antimicrobial activity of synthesized complex compounds was screened against eight bacteria and four fungi using in vitro disc diffusion method respectively. The results revealed that most of the synthesized complex compounds exhibited good biological activities due to the presence of metal ion in the complexes.

\section{References:-}

1. S.K. Mandal, K. Nag, J. Chem. Soc. Dalton Trans. 1983.

2. A.VinodShelke, M. SarikaJadhav, et al. Journal of the Korean Chemical Society.2011, 55, 3.

3. D.L. Pavia, G.M. Lampman, et al. Introduction to Spectroscopy. 3rd ed., Harcourt College Publishers, New York, 2007.

4. N. Nishat, Rahis-ud-din, et al. Transition Met.Chem. 2003, $28,948$.

5. M.B.H. Howlader, C.M. Zakaria, et al. Jahangirnagar Univ J Sci. 2007, 30, 43.

6. O.A. Weber, T.W. Robinson, et al. J. Inorg. Nucl.Chem. 1971, 33, 2097.

7. L.D.L. Durantaye, T. Mc Cormick, et al. Dalton Trans. 2006, 66, 5675.

8. H.C. Lin, C.C. Huang, et al. Dalton Trans. 2007, 7, 781.

9. S. Basak, S. Sen, et al. Polyhedron. 2007, 26, 5104.

10. S. Alghool, H.F. Abd El-Halim et al. J. Mol. Struct. 2010, 983, 32.

11. A. Garoufis, S.K. Hadjikakou, et al. Coord. Chem. Rev. 2009, 253, 1384.

12. H. Naeimi, K. Rabiei, et al. Dyes Pigm. 2007, 75, 294.

13. H. Nishihara, Bull. Chem. Soc. Japan. 2004, 77, 407.

14. M. Badea, A. Emandi, et al. J. Therm. Anal. Calorim. 2003, 72, 525.

15. E. Ispir, Dyes Pigm. 2009, 82, 13.

16. R. Asgari-sabet, H. Khoshsima, Dyes Pigm. 2010, 87, 95.

17. Y.D. Kim, J.H. Cho, et al. Dyes Pigm. 2011, 89, 1.

18. A.M.A. Alaghaz, H.A. Bayoumi, et al. J. Mole. Struct. 2013, 1035, 383.

19. M.S. Asha, A. Bushra Begum A, Chem. Sci. Rev Lett. 2014, 3, 11, 735-746.

20. A.S. Munde, S.G. Shirodkar, et al. Journal of the Korean Chemical Society. 2009, 53, 407.

21. P.R. Murray, E.J. Baron, et al. Manual of Clinical Microbiology. 1995, 6, 118.

22. V. Duraipandiyan, S. Ignacimuthu, J. Ethnopharmacol. 2009, 123, 494.

23. Dilution Antifungal Susceptibility Testing of Filamentous Fungi, Approved Standard Second Edition CLSI document M38-A2. Clinical and Laboratory Standards Institute, USA. 2008, $28,1$.

24. A. Sreekanth and M.R.P. Kurup, Polyhedron, 2003, 23, 3321.

25. R. N. Prasad, M. Mathur, et al. J. Indian Chem. Soc. 2007, 84, 1202. 
26. J.A. Faniran, K.S. Patel, et al.J. Inorg. Nucl.Chem. 1974, 36, 1547.

27. A.VinodShelke, Sarika M. et al. Journal of the Korean Chemical Society. 2011, 55, 3.

28. S.K. Mandal, K. Nag, J. Chem. Soc. Dalton Trans. 1983.

29. A.VinodShelke, M. SarikaJadhav, et al. Journal of the Korean Chemical Society. 2011, 55, 3.

30. D.L. Pavia, G.M. Lampman, et al. Introduction to Spectroscopy, 3rd ed., Harcourt College Publishers, New York, 2007.

31. N. Nishat, Rahis-ud-din, et al. Transition Met.Chem. 2003, 28, 948.

32. M.B.H. Howlader, C. M. Zakariaet al. Jahangirnagar Univ J Sci, 2007, 30, 43.

33. D. P. Singh, V. Malik, et al. Russ. J. Coord. Chem. 2009, 35, 740.

34. S. Chandra, R. Kumar, Transition Met. Chem. 2004, 29, 269

35. D.P. Singh, V. Malik, et al. Russ. J. Coord. Chem. 2009, 35, 740.

36. D.P. Singh, K. Kumar, et al. J. Enzym, Inhib. Med. Chem. 2009, 24, 795.

37. M. Yamashita, J.B. Fenn, J. Phys. Chem. 1984, 88, 4451.

38. K. Abe, K. Matsufuji, et al. Inorganic Chemistry. 2002, 41, 4461.

39. S. Chandra, L.K. Gupta. Spectrochim. Acta A. 2005, 61, 269. 